\title{
Mobiliteit op de Nederlandse arbeidsmarkt
}

\author{
Citation for published version (APA):
}

Borghans, L. (1996). Mobiliteit op de Nederlandse arbeidsmarkt. Researchcentrum voor Onderwijs en Arbeidsmarkt, Faculteit der Economische Wetenschappen. ROA Working Papers No. 3 https://doi.org/10.26481/umarow.1996003

Document status and date:

Published: 01/01/1996

DOI:

10.26481/umarow.1996003

Document Version:

Publisher's PDF, also known as Version of record

\section{Please check the document version of this publication:}

- A submitted manuscript is the version of the article upon submission and before peer-review. There can be important differences between the submitted version and the official published version of record.

People interested in the research are advised to contact the author for the final version of the publication, or visit the DOI to the publisher's website.

- The final author version and the galley proof are versions of the publication after peer review.

- The final published version features the final layout of the paper including the volume, issue and page numbers.

Link to publication

\footnotetext{
General rights rights.

- You may freely distribute the URL identifying the publication in the public portal. please follow below link for the End User Agreement:

www.umlib.nl/taverne-license

Take down policy

If you believe that this document breaches copyright please contact us at:

repository@maastrichtuniversity.nl

providing details and we will investigate your claim.
}

Copyright and moral rights for the publications made accessible in the public portal are retained by the authors and/or other copyright owners and it is a condition of accessing publications that users recognise and abide by the legal requirements associated with these

- Users may download and print one copy of any publication from the public portal for the purpose of private study or research.

- You may not further distribute the material or use it for any profit-making activity or commercial gain

If the publication is distributed under the terms of Article $25 \mathrm{fa}$ of the Dutch Copyright Act, indicated by the "Taverne" license above, 


\title{
Mobiliteit op de Nederlandse arbeidsmarkt
}

\author{
Lex Borghans
}

ROA-W-1996/3

Researchcentrum voor Onderwijs en Arbeidsmarkt

Faculteit der Economische Wetenschappen en Bedrijfskunde Universiteit Maastricht

Maastricht, juli 1996 
ISBN 90-5321-183-7 


\section{Inhoud}

\section{Bladzijde}

1 Inleiding

2 Het meten van mobiliteit 2

3 Globale stromen op de arbeidsmarkt 4

4 Mobiliteit van maand tot maand 19

5 Conclusies $\quad 30$

$\begin{array}{ll}\text { Literatuur } & 31\end{array}$ 


\section{Inleiding}

De Nederlandse arbeidsmarkt wordt vaak beschreven aan de hand van standcijfers zoals de werkloosheid op een bepaald moment of de werkgelegenheid per sector, beroep of opleidingstype. Achter deze standcijfers gaan echter veelal grote stromen schuil die niet in de standcijfers tot uitdrukking komen. Zo zal ook als de werkloosheid in twee opeenvolgende jaren qua omvang vergelijkbaar is, een aanzienlijk deel van de werklozen in het eerste jaar inmiddels werk hebben gevonden, of de arbeidsmarkt hebben verlaten, terwijl gedurende dat jaar er een nieuwe groep werklozen is bijgekomen.

De laatste jaren is er voor de analyse van arbeidsmarktprocessen steeds meer interesse gekomen in deze arbeidsmarktmobiliteit. Met name het werk van Blanchard en Diamond (1989) heeft de interesse in deze stroomcijfers vergroot. Er is echter relatief weinig informatie over stromen op de Nederlandse arbeidsmarkt. De dataverzameling is nog niet aangepast aan deze verschoven belangstelling van zowel onderzoekers als beleidsmakers. Dit hangt mede samen met het feit dat het verzamelen van stroomgegevens aanzienlijk gecompliceerder te zijn dan het verzamelen van standcijfers. In deze notitie wordt daarom een overzicht gegeven van de stroomcijfers die thans beschikbaar zijn over de Nederlandse arbeidsmarkt. Dit overzicht heeft een drietal doelstellingen. Ten eerste beoogt het voor zover bekend een indicatie te geven van de omvang van enkele relevante arbeidsmarktstromen in Nederland. Ten tweede wordt hiermee duidelijk op welke punten er wel en op welke punten er nog geen stroomcijfers beschikbaar zijn, zodat de blinde vlekken in de dataverzameling getraceerd kunnen worden. Ten derde beoogt deze notitie in te gaan op de mogelijke problemen bij het verzamelen van stroomcijfers.

Men kan de stromen op de arbeidsmarkt bestuderen vanuit twee invalshoeken. Ten eerste kan er gekeken worden naar het ontstaan en verdwijnen van banen. In dat geval wordt de ontwikkeling van functies geanalyseerd ongeacht degene die op een bepaald moment deze functies vervult. In dit werkdocument wordt echter het individu als uitgangspunt genomen. Onderzocht wordt welke verschuivingen individuele aanbieders van arbeid op de arbeidsmarkt doormaken.

De verdere opbouw van deze notitie is als volgt. Allereerst wordt in paragraaf 2 kort ingegaan op de verschillende wijzen waarop mobiliteit op de arbeidsmarkt kan worden gemeten. Daarna wordt ingegaan op de empirische gegevens over mobiliteit in Nederland. Hierbij is een tweedeling gemaakt in globale mobiliteitscijfers (paragraaf 3 ) en bronnen die nauwkeurige informatie geven van alle relevante veranderingen (paragraaf 4). De globale cijfers geven een vergelijking van de positie van een individu op twee meetmomenten, terwijl de meer specifieke informatie aangeeft welke verschuivingen er in de tussenliggende periode van maand tot maand hebben plaatsgevonden. Hoofdstuk 5 besluit met enkele conclusies. 


\section{Het meten van mobiliteit}

Het vaststellen van stromen op de arbeidsmarkt is aanzienlijk gecompliceerder dan het meten van standcijfers. Voor het vaststellen van standcijfers moet in een enquête of een administratief bestand immers alleen gekeken worden naar de huidige activiteit van een individu, terwijl voor stroomcijfers overgangen getraceerd moeten worden. Dit betekent ofwel dat individuen juist op het moment van een overgang ondervraagd moeten worden, of dat in een enquête een vergelijking met het verleden moet worden gemaakt. De eerste methode vereist dat de betrokkene zich op het juiste moment meldt. Dit is in principe mogelijk bij de overgang naar werkloosheid, omdat mensen zich hiervoor, om een uitkering te krijgen, dienen aan te melden bij het arbeidsbureau. Ook voor gediplomeerde schoolverlaters, die mogelijk de arbeidsmarkt zullen betreden, is het moment van overgang makkelijk vast te stellen. Voor veel andere overgangen is een dergelijke automatische registratie echter niet aanwezig, terwijl zelfs in het geval van werkloosheid een deel van de betrokkenen zich niet zal laten administreren, omdat men geen recht op een uitkering heeft.

Doorgaans dient er dus voor het vaststellen van arbeidsmarktmobiliteit een vergelijking van de huidige positie op de arbeidsmarkt met die in het verleden te worden gemaakt. Hiervoor bestaan een drietal onderzoeksinstrumenten, te weten: een vergelijking van standcijfers op verschillende tijdstippen, paneldata en een retrospectieve vraagstelling.

Bij het vergelijken van standcijfers op verschillende tijdstippen wordt niet direct een stroom op de arbeidsmarkt waargenomen, maar kan geconstateerd worden dat een bepaalde groep in omvang is toegenomen en er dus individuen moeten zijn toegestroomd. Op deze wijze kunnen nettostromen worden geconstrueerd. Bij gebrek aan betere informatie wordt deze reconstructiemethode vaak toegepast, onder andere door Broersma en Gautier (1995) voor de constructie van cijfers over baancreatie en baanvernietiging en door Willems en De Grip (1993) voor een analyse van de in- en uitstroomprocessen op de arbeidsmarkt. Een nadeel van deze methode is echter dat alleen netto stromen kunnen worden vastgesteld. Als er binnen een onderscheiden categorie zowel in- als uitstroom plaatsvindt, wordt alleen het saldo van deze stromen waargenomen. Dit probleem kan echter gereduceerd worden door veel kleine categorieën afzonderlijk te bestuderen, zodat een zo groot mogelijk deel van de in- en uitgaande stromen in verschillende categorieën terecht komt. Omdat er doorgaans echter gebruik wordt gemaakt van een steekproef en er geen informatie over de gehele populatie beschikbaar is, kent deze opsplitsing zijn beperking. Bij te kleine groepen zal immers de steekproeffout te groot worden.

Een tweede methode om stromen op de arbeidsmarkt vast te stellen betreft de panel-enquête. Hierbij wordt eenzelfde groep personen steeds opnieuw geënquêteerd. Door de arbeidsmarktpositie van deze individuen op de afzonderlijke meetmomenten met elkaar te vergelijken, ontstaat ook een beeld van de mobiliteit, waarbij een groot deel van de steekproefonzekerheid weggenomen is doordat steeds dezelfde personen worden ondervraagd. De mogelijke problemen met een panel zijn echter van andere aard. Ten eerste 
is het vaak moeilijk gedurende lange tijd voldoende respondenten uit de aanvankelijke steekproef in het panel te houden. Vanwege non-repons of mobiliteit in en uit de doelgroep van het onderzoek, zal ook bij een panel gedeeltelijke vernieuwing moeten plaatsvinden, waardoor een deel van de stroomgegevens verloren gaat. Daarnaast kunnen personen die in eenzelfde situatie zitten dit op verschillende wijzen rapporteren. Met name problematisch in dit opzicht is de beroepsmobiliteit. Glebbeek (1993) constateert bijvoorbeeld dat de waargenomen beroepsmobiliteit op basis van paneldata veel groter is dan de werkelijke mobiliteit doordat mensen met eenzelfde functie per toeval in verschillende beroepsklassen worden ingedeeld.

Daarnaast kennen zowel de vergelijking van standcijfers als paneldata het nadeel dat alleen arbeidsmarktsituaties op een bepaald moment worden waargenomen. Als bijvoorbeeld iemand tussen twee waarnemingsmomenten in tijdelijk werkloos is geweest, wordt dit niet waargenomen. Bij een terugkeer in de oorspronkelijke positie lijkt het alsof er helemaal geen verandering heeft plaatsgevonden.

Een retrospectieve vraagstelling kan dit probleem mogelijk ondervangen. Bij een retrospectieve vraag worden stromen niet vastgesteld door enquêtes op verschillende tijdstippen met elkaar te vergelijken, maar door in één enquête zowel vragen over de huidige, als vragen over de situatie in het verleden op te nemen. Hierbij kan een onderscheid gemaakt worden naar enquêtes waarin gevraagd wordt naar de situatie op bepaalde momenten in het verleden en enquêtes waarin gevraagd wordt naar alle veranderingen over een bepaalde periode. Bij de eerste methode blijft het bezwaar bestaan dat mogelijk mobiliteit in de tussenliggende periodes niet wordt waargenomen. In de Enquête Beroepsbevolking (EBB) wordt deze laatste aanpak gevolgd, door het opnemen van vragen over de arbeidsmarktsituatie voor respectievelijk drie en twaalf maanden geleden. In het OSAaanbodpanel wordt retrospectief naar alle veranderingen over de afgelopen twee jaar gevraagd. Hierbij zijn in principe dus alle verschuivingen waar te nemen. In de HBO-Monitor wordt, ten slotte, een tussenweg gehanteerd. Door voor elke maand gedurende een lange tijdsperiode te vragen naar de actuele arbeidsmarktpositie, wordt bij benadering de mobiliteit gedurende de gehele periode gereconstrueerd.

Ook de retrospectieve vraag heeft echter nadelen. Het voornaamste bezwaar is dat mensen zich de situatie waarin men zich in het verleden bevond, niet altijd herinneren. Hierbij zal het vaker voorkomen dat men zich vergist bij de beantwoording van een vraag en zullen er onnauwkeurigheden in de beantwoording sluipen. Met name met betrekking tot de precieze timing van gebeurtenissen kan dit tot moeilijkheden leiden. Deze problemen zullen nog groter worden als er - zoals bijvoorbeeld bij de EBB - gebruik wordt gemaakt van zogenaamde proxy-interviews, waarbij niet de persoon zelf, maar een huisgenoot de vragen beantwoordt.

Bij de keuze voor een bepaalde meetmethode moeten derhalve altijd de mogelijke bezwaren meegewogen worden. Afhankelijk van het doel van de mobiliteitscijfers kunnen bepaalde methodes beter zijn dan andere. Verder is het natuurlijk van belang om te weten op welke 
wijze gegevens zijn verzameld en verder kan vergelijking van stroomcijfers die via verschillende methodes tot stand zijn gekomen inzicht geven in de mogelijke foutenmarges.

\section{Globale stromen op de arbeidsmarkt}

In deze paragraaf wordt een beeld geschetst van de globale stromen op de arbeidsmarkt, die met name de mobiliteitspatronen op de langere termijn laten zien. De meest voor de hand liggende presentatievorm van deze gegevens is een matrix die herkomst en bestemming van individuen over een bepaalde periode tegen elkaar uitzet. Tabel 3.1 geeft op deze wijze op grond van het OSA-aanbodpanel uit 1992 een overzicht van de overgangen tussen 1990 en 1992 met betrekking tot de maatschappelijke positie van de betrokkenen. In principe vergelijkt de tabel alleen de positie in 1990 met die in 1992, maar impliciet is ook informatie over de tussenliggende periode opgenomen, doordat in de laatste kolom de percentages staan weergegeven van de individuen met een bepaalde herkomst waarvoor geen verandering heeft plaatsgevonden. In de overige kolommen staan alleen degenen bij wie er wel sprake is van een verandering. De tabel geeft per categorie van herkomst in 1990 de bestemming in 1992 weer. Zo heeft van degenen die in 1990 in loondienst waren 49\% geen verandering ondergaan. $43 \%$ is van baan veranderd, al dan niet bij dezelfde werkgever. $2 \%$ is werkloos geworden, terwijl $5 \%$ de arbeidsmarkt heeft verlaten.

Tabel 3.1

Overgangen van positie op de arbeidsmarkt van 1990 naar 1992 op basis van OSA-aanbodpanel

\begin{tabular}{|c|c|c|c|c|c|c|c|}
\hline \multirow[b]{4}{*}{ Positie in 1990} & \multicolumn{6}{|c|}{ Arbeidsmarktpositie in 1992} & \multirow{3}{*}{$\begin{array}{l}\text { Geen } \\
\text { verandering }\end{array}$} \\
\hline & \multirow[b]{2}{*}{$\begin{array}{l}\text { Loon- } \\
\text { dienst }\end{array}$} & \multicolumn{3}{|c|}{ Verandering } & & & \\
\hline & & Zelfstandige & Meewerkend & $\begin{array}{l}\text { Geen werk } \\
\text { op zoek }\end{array}$ & $\begin{array}{l}\text { Geen werk } \\
\text { niet } \\
\text { op zoek }\end{array}$ & $\begin{array}{l}\text { Dag- } \\
\text { opleiding }\end{array}$ & \\
\hline & $\%$ & $\%$ & $\%$ & $\%$ & $\%$ & $\%$ & $\%$ \\
\hline Loondienst & 43 & 1 & 0 & 2 & 5 & 0 & 49 \\
\hline Zelfstandige & $\varepsilon$ & 13 & 0 & 1 & 5 & 0 & 74 \\
\hline Meewerkend & 6 & 6 & 9 & 0 & 6 & 0 & 72 \\
\hline Geen werk, op zoek & K 56 & 2 & 0 & 11 & 11 & 0 & 20 \\
\hline Geen werk, niet op & zoek 7 & 0 & 0 & 2 & 1 & 0 & 89 \\
\hline Dienstplicht & 100 & 0 & 0 & 0 & 0 & 0 & 0 \\
\hline Dagopleiding & 71 & 1 & 0 & 11 & 1 & 2 & 14 \\
\hline
\end{tabular}

De grootste verschuivingen vinden plaats bij degenen die in 1990 de dienstplicht vervulden, zij die een dagopleiding volgden en de werklozen. Aangezien dienstplicht geen twee jaar duurt is bij deze groep iedereen van positie veranderd. Opvallend is dat de gehele groep werk heeft gevonden. Ook het overgrote deel van degenen die een dagopleiding volgde heeft inmiddels de school verlaten. De omvang van deze mutatie komt echter voort uit het feit dat in het panel vrijwel alleen personen zijn opgenomen die in 1990 al aan het einde van hun studie zaten. Bij 
een in dit opzicht meer representatieve steekproef zou de uitstroom uit het onderwijs uiteraard geringer zijn. Ten slotte is interessant dat 31\% van degenen die in 1990 geen werk hadden, maar wel op zoek waren naar werk, ook in 1992 werkloos zijn. 56\% heeft werk gevonden en $11 \%$ zoekt niet meer naar werk. Degenen die ook in 1992 werkloos zijn kunnen echter in de tussentijd, tussen de twee meetmomenten in, wel werk hebben gehad. Voor $11 \%$ is dit inderdaad het geval, terwijl voor $20 \%$ er geen verandering van situatie heeft plaatsgevonden.

Tabel 3.2 presenteert vergelijkbare informatie voor de periode 1992-1994 op een minder gedetailleerde wijze. Deze tabel is rechtstreeks ontleend aan Kunnen e.a. (1995). Interessant is dat vergeleken met de vorige tabel een overeenkomstig percentage van de werklozen in 1992 ook in 1994 geen werk heeft. Vanwege het feit dat in deze tabel echter alleen een verband wordt gelegd tussen de situatie aan het begin en aan het eind van de periode, en dus geen gebruik wordt gemaakt van de retrospectieve informatie, is niet duidelijk of de betreffende personen de gehele periode van twee jaar werkloos zijn geweest.

Tabel 3.2

Overgangen van positie op de arbeidsmarkt van 1992 naar 1994 op basis van OSA-aanbodpanel

\begin{tabular}{lcccc} 
& \multicolumn{2}{c}{$\begin{array}{c}\text { Arbeidsmarktpositie in } 1994 \\
\text { Werkzoekend } \\
\text { Betaalde } \\
\text { Werkkring } \\
\%\end{array}$} & $\begin{array}{c}\text { Niet- } \\
\text { participerend } \\
\%\end{array}$ & Totaal \\
\hline Arbeidsmarktpositie in 1992 & & & & $\%$ \\
Werkzoekend & 34 & 45 & 21 & 100 \\
Werkkring & 3 & 91 & 6 & 100 \\
Niet-participerend & 2 & 7 & 91 & 100 \\
\hline
\end{tabular}

Bron: Kunnen e.a. (1995)

Op grond van het OSA-aanbodpanel kan een vergelijking gemaakt worden van de maatschappelijke positie van de bevolking op twee meetmomenten. Op vergelijkbare wijze vergelijkt Trimp (1995) met behulp van het Inkomens Panelonderzoek (IPO) overgangen met betrekking tot de inkomensbronnen van individuen. Tabel 3.3 geeft deze overgangen voor de periode van één jaar (1989-1990) weer, terwijl in tabel 3.4 een vijfjarige periode wordt gepresenteerd (1989-1994). Na één jaar blijkt van zowel de werknemers als de ambtenaren $9 \%$ van inkomensbron te zijn veranderd. $5 \%$ van de ambtenaren wordt werknemer en maar liefst $4 \%$ van de werknemers heeft na een jaar geen loon of uitkering meer. $2 \%$ van de werknemers blijkt een jaar later een WW-uitkering te ontvangen en $1 \%$ heeft recht op een WAO-uitkering. Op de diagonaal van de matrix komt naar voren welk deel van de betreffende groep na een jaar in dezelfde situatie zit als bij de eerste meting. De mutatie blijkt het grootst te zijn bij de WW'ers. 33\% van deze groep heeft werk gevonden als werknemer of ambtenaar, terwijl $48 \%$ nog steeds of weer opnieuw een WW-uitkering krijgt. De overigen zijn terug te vinden in diverse andere categorieën, zoals de Rww en de arbeidsongeschiktheidswet.

Tabel 3.3

Overgangen van inkomensbron volgens IPO na één jaar 


\begin{tabular}{|c|c|c|c|c|c|c|c|c|c|c|c|}
\hline & \multicolumn{11}{|c|}{ inkomensbron 1-1-1990 } \\
\hline & $\begin{array}{l}\text { Loon } \\
\text { werk- } \\
\text { nemer }\end{array}$ & $\begin{array}{l}\text { Loon } \\
\text { ambte- } \\
\text { naar }\end{array}$ & WW & $\begin{array}{l}\text { WAO/ } \\
\text { AAW }\end{array}$ & Rww & ABW & Pensioen & $\begin{array}{l}\text { Geen loon } \\
\text { of uitkering }\end{array}$ & Overleden & $\begin{array}{l}\text { Geëmi- } \\
\text { greerd }\end{array}$ & Totaal \\
\hline & $\%$ & $\%$ & $\%$ & $\%$ & $\%$ & $\%$ & $\%$ & $\%$ & $\%$ & $\%$ & $\%$ \\
\hline \multicolumn{12}{|l|}{$\begin{array}{l}\text { inkomensbron } \\
1-1-1989\end{array}$} \\
\hline Loon werknemer & 91 & 1 & 2 & 1 & 0 & 0 & 1 & 4 & 0 & 0 & 100 \\
\hline Loon ambtenaar & 5 & 91 & 0 & 0 & 0 & 0 & 2 & 1 & 0 & 0 & 100 \\
\hline WW & 31 & 2 & 48 & 1 & 5 & 1 & 3 & 8 & 0 & 0 & 100 \\
\hline WAO/AWW & 3 & 0 & 1 & 88 & 0 & 0 & 5 & 1 & 2 & 0 & 100 \\
\hline Rww & 16 & 1 & 1 & 1 & 68 & 2 & 1 & 9 & 1 & 1 & 100 \\
\hline$A B W$ & 4 & 0 & 3 & 1 & 4 & 78 & 2 & 10 & 1 & 0 & 100 \\
\hline Pensioen & 2 & 0 & 0 & 1 & 0 & 0 & 95 & 1 & 1 & 0 & 100 \\
\hline Geen inkomen & 9 & 0 & 0 & 0 & 1 & 0 & 2 & 85 & 0 & 0 & 100 \\
\hline
\end{tabular}

Bron: Trimp (1995)

Tabel 3.4

Overgangen van inkomensbron volgens IPO na vijf jaar

\begin{tabular}{|c|c|c|c|c|c|c|c|c|c|c|c|}
\hline & \multicolumn{11}{|c|}{ inkomensbron 31-12-1993 } \\
\hline & \multirow{2}{*}{$\begin{array}{l}\text { Loon } \\
\text { werk- } \\
\text { nemer } \\
\%\end{array}$} & \multirow{2}{*}{$\begin{array}{l}\text { Loon } \\
\text { ambte- } \\
\text { naar } \\
\% \\
\end{array}$} & \multirow{2}{*}{$\begin{array}{r}\text { WW } \\
\% \\
\end{array}$} & \multirow{2}{*}{$\begin{array}{c}\text { WAO/ } \\
\text { AAW } \\
\%\end{array}$} & \multirow{2}{*}{$\begin{array}{l}\text { Rww } \\
\% \\
\end{array}$} & \multirow{2}{*}{$\begin{array}{c}\text { ABW } \\
\% \\
\end{array}$} & \multirow{2}{*}{$\begin{array}{c}\text { Pensioen } \\
\\
\%\end{array}$} & \multirow{2}{*}{\multicolumn{2}{|c|}{$\begin{array}{l}\text { Geen loon Overleden } \\
\text { of uitkering } \\
\begin{array}{c}\% \\
\%\end{array}\end{array}$}} & \multirow{2}{*}{$\begin{array}{l}\text { Geëmi- } \\
\text { greerd } \\
\%\end{array}$} & \multirow{2}{*}{$\begin{array}{l}\text { Totaa } \\
\text { \% } \\
\end{array}$} \\
\hline & & & & & & & & & & & \\
\hline \multicolumn{12}{|l|}{$\begin{array}{l}\text { inkomensbron } \\
\text { 1-1-1989 }\end{array}$} \\
\hline Loon werknemer & 76 & 2 & 3 & 3 & 1 & 0 & 4 & 10 & 1 & 1 & 100 \\
\hline Loon ambtenaar & 11 & 71 & 0 & 0 & 0 & 0 & 11 & 4 & 2 & 1 & 100 \\
\hline WW & 36 & 1 & 19 & 7 & 5 & 1 & 13 & 14 & 3 & 1 & 100 \\
\hline WAO/AWW & 4 & 0 & 0 & 65 & 0 & 1 & 20 & 1 & 7 & 1 & 100 \\
\hline Rww & 28 & 3 & 3 & 2 & 37 & 6 & 3 & 16 & 2 & 2 & 100 \\
\hline ABW & 13 & 0 & 3 & 2 & 10 & 45 & 8 & 17 & 2 & 1 & 100 \\
\hline Pensioen & 2 & 0 & 0 & 0 & 0 & 0 & 91 & 0 & 6 & 0 & 100 \\
\hline Geen inkomen & 17 & 1 & 1 & 1 & 1 & 1 & 10 & 65 & 2 & 1 & 100 \\
\hline
\end{tabular}

Bron: Trimp (1995)

Tabel 3.4 laat dezelfde overgangen zien voor een vijfjarige periode. In grote lijnen geeft deze tabel eenzelfde patroon te zien als tabel 3.3. De waargenomen verschuivingen zijn in het algemeen echter aanmerkelijk groter. In sommige gevallen is de mobiliteit over de vijfjarige periode echter nauwelijks groter dan de mobiliteit over de eenjarige periode. Zo is van de WW'ers na een jaar 33\% werkzaam als werknemer of ambtenaar, terwijl dit na vijf jaar slechts $36 \%$ betreft. Dit impliceert dat er ofwel een grote groep langdurig werklozen is, of werklozen, na een periode van werk een vergrote kans hebben om weer terug te keren in de WW. Hieruit blijkt reeds dat, om dit onderscheid te kunnen maken, voor bepaalde processen meer gedetailleerde informatie, die de stromen op de arbeidsmarkt doorlopend in beeld brengt, vereist is. Een vergelijkbare geringe verschuiving tussen de eenjarige periode en de vijfjaarsperiode is te zien bij de overgang van WAO naar werk. Na een jaar heeft $3 \%$ van de WAO'ers weer werk, terwijl dit na 5 jaar slechts $1 \%$ meer betreft. 
Figuur 3.1

Kans van een werkloze op een baan na twee jaar op basis van OSA-aanbodpanel, 1986-1994, percentages (Kunnen e.a. 1995)

Door meerdere jaargangen van een enquête met elkaar te vergelijken ontstaat een beeld van de veranderingen in de mobiliteitspatronen. In figuur 3.1 tot en met 3.3 worden op deze wijze de mobiliteitsgegevens van het OSA-aanbodpanel in een langer tijdsperspectief geplaatst. Allereerst laat figuur 3.1 de ontwikkeling zien van het percentage werklozen dat twee jaar later een baan heeft. Van ' 86 -'88 tot '90-'92 loopt dit percentage op van 36\% naar 50\%'. Voor de periode ' $92-' 94$ is dit percentage met $45 \%$ echter weer lager.

Omdat de overgang van werk naar werkloos in de periode 1992-1994 juist kleiner is geworden, heeft deze lagere uittrede uit de werkloosheid een verschuiving bewerkstelligd in de opbouw van het werklozenbestand naar werkloosheidsduur. Figuur 3.2 laat zien dat terwijl in de periode tot 1992 het aandeel kortdurig werklozen toenam, en met name tussen 1990 en 1992 het aandeel langdurig werklozen (van meer dan 35 maanden) flink afnam, tussen 1992 en 1994 de werkloosheid van minder dan 5 maanden relatief weer afnam, terwijl de groepen die langer werkloos zijn aan relatief belang wonnen.

Figuur 3.2

Samenstelling werklozenbestand naar werkloosheidsduur op basis van OSA-aanbodpanel, 1985-1992, procentuele aandelen (Kunnen e.a., 1995)

1. $\quad$ Deze overgang in Kunnen e.a. (1995) correspondeert overigens niet geheel met tabel 3.1. Kennelijk is er sprake van een definitieverschil. 
Figuur 3.3

Baanveranderingen 1983-1994 als percentage van aantal banen (Kunnen e.a., 1995)

In figuur 3.3 wordt de ontwikkeling van het aantal baanveranderingen in de loop van de tijd weergegeven. Baanveranderingen worden door de Kunnen e.a. (1995) gedefinieerd als verschuivingen van werkenden van de ene baan naar de andere baan. In de periode 1983 tot 1988 is het percentage baanveranderingen aanzienlijk toegenomen van minder dan $6 \%$ tot meer dan 14\%. Na 1990 heeft zich echter een duidelijke daling ingezet tot ongeveer $8 \%$ in 
1994.

Het is echter van belang om erop te wijzen dat het percentage baanveranderingen sterk kan reageren op kleine veranderingen in de arbeidsmarktprocessen. De Grip , Meijboom en Willems (1993) laten zien dat het ontstaan van een nieuwe baan aanleiding kan geven tot een keten van verschuivingen op de arbeidsmarkt. Als een vacature vaak vervuld wordt door een reeds werkzame persoon, ontstaat bij de baan die deze persoon achterlaat ook weer een vacature. Deze keten stopt pas als een vacature wordt vervuld door een nieuwkomer op de arbeidsmarkt, of als een werkgever besluit een vrijvallende baan niet opnieuw te bezetten. Afhankelijk van deze twee mogelijkheden kan de lengte van een vacatureketen, en daarmee de mobiliteit op de arbeidsmarkt derhalve sterk fluctueren.

Een panel als het OSA-aanbodpanel blijkt dus een goed instrument om mobiliteitsprocessen op de arbeidsmarkt in kaart te brengen. Een bezwaar van het OSA-panel, maar ook van het Sociaal Economisch Panel (SEP) van het CBS is dat de steekproefomvang niet voldoende is om de stroomgegevens uit te splitsen naar een groot aantal categoriën, zoals bijvoorbeeld sector, beroep, of opleiding. Ook speciale doelgroepen voor het beleid zullen doorgaans niet voldoende gerepresenteerd zijn in een panel om er met voldoende statistische betrouwbaarheid informatie over te kunnen presenteren.

Figuur 3.4

Hoofdactiviteit van vluchtelingen afgezet tegen hoofdactiviteit een half jaar later (Brink e.a., 1996)

Een dergelijk bezwaar kan opgelost worden door een panel samen te stellen dat speciaal uit leden van deze doelgroep bestaat, of door een veel bredere arbeidsmarktenquête te gebruiken voor het verzamelen van stroomgegevens. Een voorbeeld van een dergelijk ad hoc panel wordt gegeven in figuur 3.4. Dit figuur is ontleent aan Brink e.a. (1996) die een arbeidsmarkt-onderzoek uitvoerden onder asielzoekers uit Iran, Somalië en voormalig Joegoslavië. Tussen de twee meetmomenten bevindt zich een periode van een half jaar. De 
figuur laat zien dat uit alle onderscheiden categoriën, vluchtelingen doorstromen naar de categorie werkend, maar dat omgekeerd werkenden alleen doorstromen naar opleiding en dus niet opnieuw werkloos worden.

Figuur 3.5

Percentage baanwisselaars 1987-1994 volgens de EBB (Hofman, 1996)

Een alternatieve databron, die over de volle breedte van de arbeidsmarkt een substantiële dekking heeft, en daardoor dus ook geschikt is voor verbijzonderingen van stroomcijfers naar diverse categorieën is de Enquête Beroeps-Bevolking (EBB). De EBB bevat ongeveer 1\% van de bevolking tussen 15 en 65 jaar. Slechts een klein deel van deze steekproef heeft een panelkarakter, maar de EBB bevat wel retrospectieve vragen, zodat ook hieruit in principe stroomcijfers kunnen worden afgeleid. Tot op heden is het CBS echter zeer terughoudend in het naar buiten brengen van dergelijke stroomcijfers. In Hofmans (1996) worden echter enkele globale mobiliteitscijfers op basis van de EBB gepresenteerd. Figuur 3.5 geeft een beeld van het percentage 'baanwisselaars' volgens de EBB. Het patroon in deze cijfers is in grote lijnen vergelijkbaar met het patroon in figuur 3.3 op basis van het OSA-panel. De totale omvang van de baan-baan-mobiliteit is echter lager in de CBS-cijfers dan in de OSA-cijfers. Een belangrijk verschil tussen beide gegevens is echter dat het CBS alleen baan-baan-mobiliteit van personen met een baan met een contractperiode van minstens 1 jaar in de analyse betrekt, terwijl bij de OSA-gegevens de mobiliteit van alle werkenden wordt meegenomen. Verder is de terugval in de mobiliteit bij de EBB-gegevens veel sterker dan volgens de OSA-gegevens. Het is niet duidelijk waardoor dit verschil wordt veroorzaakt. Mogelijk is in de laatste jaren met name de mobiliteit van personen met een niet-flexibel contract sterk afgenomen.

In figuur 3.6 worden de percentages baanwisselaars op basis van de retrospectieve vraag van 
de EBB, uitgesplitst naar leeftijd. De figuur bevestigt dat de meest omvangrijke baan-baanmobiliteit plaatsvindt in de jongere leeftijdscategorieën.

Figuur 3.6

Baanwisselaars in procenten van het aantal werknemers per leeftijdsklasse, 1994

Tabel 3.5

Baanmobiliteit naar opleidingsniveau, 1994

\begin{tabular}{lcc}
\hline & Totaal & $\begin{array}{c}\text { Baanwisselaar } \\
\%\end{array}$ \\
\hline Totaal & 5.222 .000 & 4 \\
Geslacht & & \\
$\quad$ Man & 3.260 .000 & 4 \\
$\quad$ Vrouw & 1.963 .000 & 4 \\
Etniciteit & & \\
$\quad$ Autochtonen & 4.785 .000 & 4 \\
$\quad$ Allochtonen & 437.000 & 4 \\
\hline
\end{tabular}

In 1994 veranderde volgens de EBB 4\% van de werknemers met een niet-flexibel contact van baan. In tabel 3.5 en 3.6 wordt dit cijfer uitgesplitst naar geslacht, ethniciteit en onderwijsniveau. Allereerst laat tabel 3.5 zien dat de baan-baan-mobiliteit van vrouwen niet afwijkt van die van mannen en dat er ook geen verschillen zijn tussen allochtonen en autochtonen. De opsplitsing naar opleidingsniveau in tabel 3.6 geeft wel een divers beeld te zien. De mobiliteit blijkt te stijgen met het opleidingsniveau. Terwijl in 1994 3\% van de werkenden met een niet flexibel contract met alleen basisonderwijs van baan veranderde, was deze mobiliteit voor WO'ers $6 \%$. Voor een deel zal dit verschil echter veroorzaakt worden door 
een verschil in de leeftijdsopbouw van beide groepen.

Tabel 3.6

Baanmobiliteit naar geslacht en etniciteit in 1994

\begin{tabular}{|c|c|c|c|}
\hline & Totaal & $\begin{array}{c}\text { Baanwisselaar } \\
\%\end{array}$ & \\
\hline Totaal & 5.222 .000 & 4 & \\
\hline $\begin{array}{l}\text { BO } \\
\text { MAVO,LBO } \\
\text { HAVO/VWO,MBO } \\
\text { HBO } \\
\text { WO }\end{array}$ & $\begin{array}{r}449.000 \\
1.203 .000 \\
2.266 .000 \\
909.000\end{array}$ & $\begin{array}{r}3 \\
4 \\
4 \\
4 \\
387.000\end{array}$ & 6 \\
\hline
\end{tabular}

Bron: Hofman (1996)

De retrospectieve vraag in de EBB wordt dus nog niet gebruikt om op een lager aggregatieniveau een beeld van de arbeidsmarktstromen te krijgen. Wel kan de EBB benut worden om door middel van het vergelijken van standcijfers in verschillende jaren een dergelijk beeld te krijgen. Deze methode wordt gevolgd bij het opstellen van de arbeidsmarktprognoses in ROA (1995a en b). In combinatie met gegevens over de uitstroom van leerlingen uit het onderwijs kan op deze wijze een beeld geschetst worden van de verschuivende vraag-aanbodverhoudingen per opleidingstype. Tabel 3.7 geeft de globale cijfers van deze ontwikkelingen in zowel de afgelopen 4 jaar (1990-1994) als de prognoseperiode 1995-2000. Om inzicht te krijgen in de mogelijkheden voor nieuwkomers op de arbeidsmarkt, wordt in deze tabel de baan-baan-mobiliteit buiten beschouwing gelaten. Relevant in dit opzicht zijn alleen de baanopeningen en niet al de verschuivingen in de vacatureketen afzonderlijk. De tabel laat zien dat het aantal baanopeningen dat ontstaat door de uitstroom van werkenden aanzienlijk groter is dan het aantal baanopeningen vanwege een werkgelegenheidstoename. In de periode 1990-1994 is er een jaarlijkse uitstroom van 2,2\% terwijl de uitbreidingsvraag 1,0\% bedraagt. In de prognoseperiode 1995-2000 zal de werkgelegenheidstoename zakken tot $0,8 \%$, maar zal, vooral vanwege de vergrijzing, de arbeidsmarktuitstroom toenemen tot maar liefst 3,3\% per jaar. Tegenover deze baanopeningen staat de instroom van schoolverlaters. Deze instroom zakt van $3,7 \%$ in de periode $1990-1994$ tot $3,4 \%$ per jaar in de prognoseperiode.

Tabel 3.7

Arbeidsmarktontwikkeling 1990-1994 en prognoses voor 1995-2000 (gemiddelde procentuele groei per jaar)

$1990-1994$

$\%$

Werkgelegenheidstoename

Arbeidsmarktuitstroom
1,0

2,2
0,8

$1995-2000$

$\%$

3,3 
Bron: ROA (1995a)

De arbeidsmarktinstroom van leerlingen wordt in grote mate bepaald door aan de ene kant de ontwikkeling in de aantallen gediplomeerden en aan de andere kant de keuze van deze leerlingen om al dan niet verder te studeren. Dit doorstudeergedrag kan binnen een niveau sterk variëren tussen opleidingen. Tabel 3.8 geeft daarom een uitgebreide beschrijving van deze stromen naar andere opleidingen en naar de arbeidsmarkt. Hierbij wordt de stroom naar inservice-onderwijs en leerlingwezen apart onderscheiden. De gegevens zijn gebaseerd op de schoolverlatersenquêtes HBO-Monitor en RUBS. Omdat het WO nog geen landelijke enquête onder afgestudeerden kent, ontbreken cijfers voor het universitair onderwijs. De tabel laat echter goed zien dat een enquête die gericht is op een specifieke doelgroep, bij de mobiliteitsprocessen beleidsmatig zeer relevant zijn, zeer gedetailleerde informatie over de sterk uiteenlopende stromen kan verstrekken.

In ROA (1995 a en b) worden de stromen uit tabel 3.7 uitgespitst naar opleidingstype en beroepsklasse. In de tabellen 3.9 tot en met 3.11 worden de instroom van schoolverlaters op de arbeidsmarkt en de vervangingsvraag gepresenteerd. Te zamen met de uitbreidingsvraag - die geen mobiliteit van een individu weerspiegelt, maar juist de creatie van een baan aan de vraagkant - vormen zij de voornaamste vraag- en aanbodcomponenten op basis waarvan de Indicator Toekomstige Arbeidsmarktsituatie (ITA) wordt vastgesteld.

De gegevens over de arbeidsmarktinstroom van schoolverlaters zijn gebaseerd op de Referentieraming van het Ministerie van Onderwijs, Cultuur en Wetenschappen (1995). Op basis van additionele informatie over onderwijsstromen zijn deze prognoses verder verbijzonderd naar opleidingstype. Daarnaast is op basis van gegevens over de herkomst van ongediplomeerden en talrijke bronnen over stromen in het niet-reguliere onderwijs een herverdeling opgesteld, waardoor de gehele instroom is opgesplitst naar het hoogst behaalde diploma. 
Tabel 3.8

Participatie schoolverlaters in vervolgopleidingen per opleidingsrichting, 1994

\begin{tabular}{lrcc}
\hline Opleidingstype en -richting & $\begin{array}{r}\text { vervolgopleiding } \\
\text { (excl. LLW) } \\
\%\end{array}$ & typering & $\begin{array}{c}\text { LLW/Inservice } \\
\%\end{array}$ \\
\hline
\end{tabular}

MAVO, VBO

\begin{tabular}{|c|c|c|c|c|}
\hline $\begin{array}{l}\text { MAVO en onderbouw HAVO/VWO } \\
\text { VBO land- en tuinbouw }\end{array}$ & $\begin{array}{l}91 \\
70\end{array}$ & $\begin{array}{l}\text { erg hoog } \\
\text { erg hoog }\end{array}$ & $\begin{array}{r}4 \\
19\end{array}$ & $\begin{array}{l}\text { gemiddeld } \\
\text { gemiddeld }\end{array}$ \\
\hline VBO technisch & & & & \\
\hline VBO bouwtechniek & 37 & gemiddeld & 43 & erg hoog \\
\hline VBO installatietechniek & 42 & gemiddeld & 46 & erg hoog \\
\hline VBO metaalkunde & 45 & hoog & 40 & hoog \\
\hline VBO motorvoertuigentechniek & 42 & gemiddeld & 45 & erg hoog \\
\hline VBO elektrotechniek & 66 & erg hoog & 26 & hoog \\
\hline VBO grafische techniek & 6 & hoog & 21 & gemiddeld \\
\hline VBO consumptieve techniek & 42 & gemiddeld & 39 & hoog \\
\hline VBO textiel- en ledertechniek & 55 & hoog & 18 & gemidde \\
\hline VBO economisch-administratief & & & & \\
\hline VBO kantoorpraktijjk & 78 & erg hoog & 9 & gemidde \\
\hline VBO verkooppraktijk & 71 & erg hoog & 13 & gemidde \\
\hline VBO verzorgend & & & & \\
\hline VBO verzorging & 74 & erg hoog & 14 & gemidde \\
\hline VBO uiterlijke verzorging & 39 & gemiddeld & 42 & erg hoog \\
\hline
\end{tabular}

HAVO/VWO, MBO

\begin{tabular}{|c|c|c|c|c|}
\hline HAVO/VWO bovenbouw & & & & \\
\hline $\begin{array}{l}\text { HAVO } \\
\text { VWO }\end{array}$ & 92 & erg hoog & 1 & erg laag \\
\hline MBO landbouw en natuurlijke omgeving & & & & \\
\hline KMBO agrarisch & 25 & gemiddeld & 32 & hoog \\
\hline MBO MAS-A land- en tuinbouw & 63 & hoog & 0 & erg laag \\
\hline $\begin{array}{l}\text { MBO MAS-B land- en tuinbouw } \\
\text { MBO technisch laboratorium }\end{array}$ & 11 & erg laag & 12 & gemiddeld \\
\hline KMLO & 25 & gemiddeld & 2 & laag \\
\hline $\mathrm{MBO}$ chemisch laboratorium & 45 & hoog & 0 & erg laag \\
\hline MBO technisch & & & & \\
\hline KMBO metaalbewerking & 18 & laag & 10 & gemiddeld \\
\hline KMBO motorvoertuigentechniek & 16 & laag & 38 & hoog \\
\hline KMBO elektrotechniek & 28 & gemiddeld & 27 & hoog \\
\hline KMBO consumptieve techniek & 20 & laag & 40 & hoog \\
\hline MBO bouwkunde & 43 & hoog & 1 & erg laag \\
\hline MBO weg- en waterbouwkunde & 33 & gemiddeld & 0 & erg laag \\
\hline MBO metaalkunde & 35 & gemiddeld & 2 & laag \\
\hline MBO werktuigbouwkunde & 45 & hoog & 1 & erg laag \\
\hline MBO motorvoertuigentechniek & 43 & hoog & 2 & laag \\
\hline MBO elektrotechniek & 46 & hoog & 2 & laag \\
\hline MBO procestechniek & 52 & hoog & 0 & erg laag \\
\hline MBO textiel- en ledertechniek & 27 & gemiddeld & 2 & laag \\
\hline MBO haven en vervoer & 25 & gemiddeld & 1 & erg laag \\
\hline $\begin{array}{c}M B O \text { verpleging en medische assistentie } \\
\mathrm{MBO} \text { verpl. en ziekenverzoraing }\end{array}$ & & & & \\
\hline $\begin{array}{l}\text { MBO verpl. en ziekenverzorging } \\
\text { MBO assistent gezondheidszora }\end{array}$ & 49 & hoog & $\begin{array}{r}24 \\
9\end{array}$ & $\begin{array}{l}\text { hoog } \\
\text { gemiddeld }\end{array}$ \\
\hline MBO medisch laboratorium & 27 & gemiddeld & 5 & gemiddeld \\
\hline
\end{tabular}

Tabel 3.8 (vervolg)

Participatie schoolverlaters in vervolgopleidingen per opleidingsrichting, 1994 


\begin{tabular}{|c|c|c|c|c|}
\hline Opleidingstype en -richting & $\begin{array}{l}\text { ling } \\
\text { W) } \\
\% \\
\end{array}$ & typering & $\begin{array}{c}\text { LLW/Inservice } \\
\qquad \% \\
\end{array}$ & typering \\
\hline \multicolumn{5}{|l|}{ MBO economisch-administratief } \\
\hline KMBO detailhandel & 27 & gemiddeld & 13 & gemiddeld \\
\hline KMBO administratie & 34 & gemiddeld & 8 & gemiddeld \\
\hline MBO handel & 32 & gemiddeld & 2 & laag \\
\hline MBO administratie & 61 & hoog & 1 & erg laag \\
\hline MBO commercieel & 50 & hoog & 2 & laag \\
\hline MBO secretarieel & 25 & gemiddeld & 1 & erg laag \\
\hline MBO bestuurlijk & 54 & hoog & 0 & erg laag \\
\hline MBO sociale arbeid & 62 & hoog & 2 & laag \\
\hline \multicolumn{5}{|l|}{ MBO verzorgend } \\
\hline KMัBO verzorging & 31 & gemiddeld & 28 & hoog \\
\hline MBO agogisch werk & 41 & gemiddeld & 11 & gemiddeld \\
\hline MBO verzorging & 11 & erg laag & 31 & hoog \\
\hline MBO mode en kleding & 40 & gemiddeld & 5 & gemiddeld \\
\hline MBO activiteitenbegeleiding & 27 & gemiddeld & 3 & gemiddeld \\
\hline \multicolumn{5}{|l|}{ MBO horeca en uiterlijke verzorging } \\
\hline MBO horeca & 29 & gemiddeld & 0 & erg laag \\
\hline MBO civ. en cons.-techn. dienster & n33 & gemiddeld & 8 & gemiddeld \\
\hline MBO uiterlijke verzorging & 22 & gemiddeld & 6 & gemiddeld \\
\hline \multicolumn{5}{|l|}{ HBO } \\
\hline \multicolumn{5}{|l|}{ HBO onderwijs } \\
\hline HBO basisonderwijzer & 9 & erg laag & n.v.t. & n.v.t. \\
\hline $\begin{array}{l}\text { HBO leraar agrarisch } \\
\text { HBO leraar kunst/expressie }\end{array}$ & 5 & erg laag & & \\
\hline $\begin{array}{l}\text { HBO leraar kunst/expressie } \\
\text { HBO leraar voortgezet onderwijs }\end{array}$ & $\begin{array}{l}20 \\
15\end{array}$ & $\begin{array}{l}\text { laag } \\
\text { laag }\end{array}$ & & \\
\hline HBO tolk en vertaler & 31 & gemiddeld & & \\
\hline HBO agrarisch & 17 & laag & & \\
\hline HBO technisch laboratorium & 23 & gemiddeld & & \\
\hline \multicolumn{5}{|l|}{ HBO technisch } \\
\hline $\begin{array}{l}\text { HBO (weg- en water)bouwkunde } \\
\text { HBO werktuigbouwkunde }\end{array}$ & $\begin{array}{l}17 \\
13\end{array}$ & laag & & \\
\hline HBO elektrotechiek & 16 & laag & & \\
\hline \multirow{3}{*}{\multicolumn{5}{|c|}{$\begin{array}{ll}\text { HBO haven en vervoer } & 8 \\
\text { HBO medisch analist } & 8 \\
\text { HBO verpleging en paramedisch } & \end{array}$}} \\
\hline & & & & \\
\hline & & & & \\
\hline $\begin{array}{l}\text { HBO verpleegkunde } \\
\text { HBO (fysio-)therapie }\end{array}$ & $\begin{array}{r}12 \\
9\end{array}$ & erg laag & & \\
\hline \multicolumn{5}{|l|}{ HBO economisch-ad'ministratief } \\
\hline $\mathrm{HBO}$ bedrijfseconomie & 22 & gemiddeld & & \\
\hline HBO accountancy & 2 & erg laag & & \\
\hline HBO bedrijfsinformatica & 19 & laag & & \\
\hline HBO toerisme & 14 & laag & & \\
\hline HBO commerciele economie & 21 & gemiddeld & & \\
\hline HBO technische bedrijfskunde & 23 & gemiddeld & & \\
\hline HBO bestuurlijk-juridisch & 30 & gemiddeld & & \\
\hline $\begin{array}{l}\text { HBO sociaal-cultureel } \\
\text { HBO welziinswerk/sociaal }\end{array}$ & & & & \\
\hline HBO welzijnswerk/sociaal & 12 & laag & & \\
\hline $\begin{array}{l}\text { HBO personeelswerk } \\
\text { HBO journalistiek }\end{array}$ & 12 & laag & & \\
\hline HBO kunst & $\begin{array}{r}15 \\
9\end{array}$ & $\begin{array}{l}\text { laag } \\
\text { erg laag }\end{array}$ & & \\
\hline
\end{tabular}

Bron: ROA (1995b)

Tabel 3.9 geeft zowel absoluut als relatief de grootste stromen van het onderwijs naar de arbeidsmarkt. Absoluut gezien blijken de arbeidsmarktinstroom van basisonderwijs, MAVO en HAVO/VWO tot de grootste categorieën te behoren. In deze groepen gaat het vooral om 
ongediplomeerden uit de vervolgopleidingen en in veel mindere mate om rechtstreekse uitstroom uit het onderwijs. Relatief gezien - dat wil zeggen in verhouding met het aantal werkenden met deze opleidingsachtergrond - is er hier echter geen sprake van grote stromen. Verder zijn het vooral enkele opleidingen op MBO-niveau die absoluut gezien tot de grootste behoren. Op HBO-niveau zijn onderwijs en sociaal-cultureel getalsmatig van grote omvang, en op WO-niveau geldt dit voor sociaal-cultureel.

Tabel 3.9

Opleidingstypen met absoluut of relatief gezien de hoogste instroom van schoolverlaters 1995-2000 (totaal aantal en gemiddeld jaarlijks percentage)

\begin{tabular}{|c|c|c|c|c|c|}
\hline \multirow[t]{2}{*}{ Opleidingstype } & \multicolumn{2}{|c|}{ Prognose 1995-2000 } & \multirow[b]{2}{*}{ typering } & \multicolumn{2}{|c|}{$1990-1994$} \\
\hline & aantal & $\%$ & & $\%$ & typering \\
\hline \multicolumn{6}{|l|}{ Absoluut } \\
\hline MBO/LLW handel & 89.500 & 5,0 & gemiddeld & 3,5 & gemiddeld \\
\hline HAVO/VWO bovenbouw & 87.500 & 5,1 & gemiddeld & 6,5 & hoog \\
\hline MBO/LLW verzorging & 62.700 & 5,2 & hoog & 5,2 & gemiddeld \\
\hline Basisonderwijs & 46.900 & 1,8 & laag & 1,9 & laag \\
\hline MBO/LLW verpleging en med. assistentie & 44.800 & 4,5 & gemiddeld & 5,7 & hoog \\
\hline HBO onderwijs & 39.900 & 2,9 & gemiddeld & 2,7 & laag \\
\hline HBO sociaal-cultureel & 31.400 & 4,9 & gemiddeld & 3,2 & gemiddeld \\
\hline MBO/LLW elektrotechniek & 29.000 & 3,7 & gemiddeld & 4,5 & gemiddeld \\
\hline MBO/LLW bouwkunde & 27.600 & 3,1 & gemiddeld & 3,8 & gemiddeld \\
\hline MBO/LLW administratie & 26.800 & 5,2 & hoog & 7,7 & erg hoog \\
\hline WO sociaal cultureel & 26.500 & 5,8 & hoog & 6,0 & hoog \\
\hline MAVO, onderbouw HAVO/VWO & 24.500 & 1,2 & laag & 1,6 & laag \\
\hline \multicolumn{6}{|l|}{ Relatief } \\
\hline HBO commerciële economie & 12.300 & 9,8 & erg hoog & 10,4 & erg hoog \\
\hline VBO bewaking & 6.000 & 9,6 & erg hoog & 9,2 & erg hoog \\
\hline WO bedrijfskunde & 5.700 & 9,4 & erg hoog & 6,9 & hoog \\
\hline HBO technische bedrijfskunde & 6.500 & 8,6 & erg hoog & 7,3 & erg hoog \\
\hline WO kunst & 4.200 & 8,1 & erg hoog & 7,1 & erg hoog \\
\hline WO werktuigbouwkunde & 4.100 & 8,1 & erg hoog & 5,2 & gemiddeld \\
\hline WO informatica & 1.800 & 7,5 & erg hoog & 8,1 & erg hoog \\
\hline HBO bedrijfseconomie & 9.200 & 7,2 & erg hoog & 7,4 & erg hoog \\
\hline WO juridisch & 18.800 & 6,9 & erg hoog & 8,3 & erg hoog \\
\hline WO econom(etr)ie en accountancy & 17.200 & 6,9 & erg hoog & 7,0 & erg hoog \\
\hline WO letteren & 15.400 & 6,3 & hoog & 8,0 & erg hoog \\
\hline WO elektrotechniek en tech. informatica & 4.800 & 6,2 & hoog & 6,1 & hoog \\
\hline
\end{tabular}

Bron: ROA (1995a)

Relatief gezien is het beeld van grote stromen van het onderwijs naar de arbeidsmarkt geheel anders. Het gaat hierbij vooral om opleidingen die qua omvang gestegen zijn, zodat de instroom relatief hoog is vergeleken met het aantal reeds werkzame personen. Het gaat hierbij vooral om WO-opleidingen. Daarnaast geeft tabel 3.9 een drietal HBO-opleidingen aan met een relatief hoge instroom: HBO commerciële economie, technische bedrijfskunde en bedrijfseconomie. In tegenstelling tot de meeste WO-opleidingen blijkt bij deze drie HBOopleidingen de vraag minder snel toe te nemen dan het aanbod van nieuwkomers, waardoor de perspectieven voor deze opleidingen matig of slecht zijn. Op lagere niveaus is alleen de 
instroom van VBO bewaking relatief erg hoog. Ook hier gaat het om een betrekkelijke jonge opleiding.

Tabel 3.10

Opleidingstypen met absoluut of relatief gezien de hoogste vervangingsvraag 1995-2000 (totaal aantal en gemiddeld jaarlijks percentage)

\begin{tabular}{llccc} 
Opleidingstype & $\begin{array}{l}\text { Prognose } \\
\text { aantal }\end{array}$ & $\% 95-2000$ & \multicolumn{2}{c}{$1990-1994$} \\
& & typering & $\%$ & typering \\
\hline
\end{tabular}

\section{Absoluut}

Basisonderwijs

MBO/LLW handel

MAVO, onderbouw HAVO/VWO

$\mathrm{HBO}$ onderwijs

VBO verzorging

MBO/LLW verpleging en med. assistentie

HAVO/VWO bovenbouw

$\mathrm{MBO} / \mathrm{LLW}$ verzorging

MBO/LLW bouwkunde

VBO mechanische techniek

MBO/LLW landbouw en natuurlijke omgeving
68.900

64.000

55.800

50.900

39.100

34.300

33.000

31.500

26.800

21.100

19.100

\section{2,6}

3,7

2,6

3,7

3,6

3,5

2,0

2,7

3,0

2,9

2,6 gemiddeld

erg hoog

gemiddeld

erg hoog

hoog

hoog

laag

gemiddeld

gemiddeld

gemiddeld

gemiddeld
1,4

2,9

1,6

1,6

1,9

2,0

1,7

1,9

2,6

1,7

2,4 erg laag

gemiddeld

erg laag

erg laag

laag

laag

erg laag

laag gemiddeld erg laag laag

Relatief

WO theologisch

VBO textiel- en ledertechniek

WO dier-, genees- en tandheelkunde

$\mathrm{HBO}$ onderwijs

MBO/LLW handel

MBO/LLW textiel- en ledertechniek

MBO/LLW fijnmechanische techniek

$\mathrm{HBO}$ bestuurlijk-juridisch

HBO accountancy

1.700

6.900

5,6

erg hoog

$\begin{array}{ll}5,2 & \text { erg hoog } \\ 4,1 & \text { erg hoog }\end{array}$

11.900

50.900

64.000

7.300

3.100

5.000

5.500

8.200

8.900

$\mathrm{MBO} / \mathrm{LLW}$ haven en vervoer

VBO verzorging

39.100

erg hoog

erg hoog

erg hoog

erg hoog

erg hoog

erg hoog

hoog

hoog

hoog

5,2

5,6

2,2

1,6

2,9

2,3

3,8

3,0

2,7

2,4

3,8

1,9 erg hoog

erg hoog

laag

erg laag

gemiddeld

laag

erg hoog

gemiddeld

gemiddeld

erg hoog

hoog

laag

Bron: ROA (1995a)

Tegenover de instroom van schoolverlaters op de arbeidsmarkt staat de uitstroom van werkzame personen. In tabel 3.10 worden deze stromen weerspiegeld in de vervangingsvraag. $\mathrm{Bij}$ de vervangingsvraag worden in tegenstelling tot de uitstroom alleen die banen meegerekend die vrijkomen door het vertrek van een medewerker die ook opnieuw vervuld worden. Ook deze tabel geeft zowel absoluut als relatief de opleidingstypen met de grootste vervangingsvraag weer. Ook hier zijn het absoluut gezien vooral basisonderwijs, MAVO en HAVO/VWO die geen groot verloop kennen. Gezien de krimpende werkgelegenheid voor deze opleidingstypen is de facto de uitstroom nog groter. Daarnaast zijn het vooral MBO-opleidingen die absoluut gezien een hoge vervangingsvraag kennen.

Ook relatief gezien is de vervangingsvraag bij een aantal MBO-opleidingen hoog. Al lange tijd is de vervangingsvraag bij WO theologie erg hoog, maar opvallend genoeg neemt de komende 
jaren ook bij WO dier-, genees- en tandheelkunde de vervangingsvraag sterk toe. Hetzelfde geldt bijvoorbeeld voor HBO accountancy. Er zijn relatief veel werkenden met deze opleidingsachtergrond die de komende jaren met pensioen of VUT zullen gaan.

Tabel 3.11

Beroepsklassen met absoluut of relatief gezien de hoogste vervangingsvraag 1995-2000 (totaal aantal en gemiddeld jaarlijks percentage)

\begin{tabular}{|c|c|c|c|c|c|}
\hline \multirow[t]{2}{*}{ Opleidingstype } & \multicolumn{2}{|c|}{ Prognose 1995-2000 } & \multirow[b]{2}{*}{ typering } & \multicolumn{2}{|c|}{ 1990-1994 } \\
\hline & aantal & $\%$ & & $\%$ & typering \\
\hline \multicolumn{6}{|l|}{ Absoluut } \\
\hline Ondernemers, uitvoerders en bedrijfskundigen & 76.100 & 4,2 & gemiddeld & 3,3 & laag \\
\hline Administrateurs en bankemployées & 63.200 & 3,3 & gemiddeld & 2,4 & erg laag \\
\hline Commercieel-administratieve employées & 49.900 & 2,6 & laag & 2,0 & erg laag \\
\hline Verkooppersoneel & 48.000 & 3,4 & gemiddeld & 2,8 & laag \\
\hline Chauffeurs en spoorwegpersoneel & 45.900 & 4,5 & hoog & 3,3 & gemiddeld \\
\hline Leerling-verpl., zieken- en kraamverzorgenden & 38.900 & 5,6 & erg hoog & 6,3 & erg hoog \\
\hline Docenten voortgezet onderwijs & 37.600 & 4,3 & gemiddeld & 2,6 & laag \\
\hline Secretaresses en typisten & 36.600 & 4,9 & hoog & 3,5 & gemiddeld \\
\hline Winkeliers en handelaars & 32.300 & 3,5 & gemiddeld & 3,2 & laag \\
\hline Portiers en schoonmaakpersoneel & 31.500 & 3,8 & gemiddeld & 2,6 & laag \\
\hline Filiaalhouders, inkopers en vertegenwoordigers & s 31.100 & 4,4 & hoog & 3,8 & gemiddeld \\
\hline Programmeurs en systeemanalisten & 30.800 & 4,2 & gemiddeld & 2,5 & laag \\
\hline
\end{tabular}

Relatief

$\begin{array}{lrrlrl}\text { Elektrotechnische opzichters en uitvoerders } & 1.800 & 5,9 & \text { erg hoog } & 4,3 & \text { gemiddeld } \\ \text { Beleidsmedewerkers en hoofdambtenaren } & 9.000 & 5,8 & \text { erg hoog } & 4,2 & \text { gemiddeld } \\ \text { Leerling-verpl., zieken- en kraamverzorgenden } & 38.900 & 5,6 & \text { erg hoog } & 6,3 & \text { erg hoog } \\ \text { Instrumentmakers en onderhoudsmonteurs } & 19.300 & 5,4 & \text { erg hoog } & 4,4 & \text { gemiddeld } \\ \text { Geestelijke verzorgers } & 2.300 & 5,3 & \text { erg hoog } & 5,3 & \text { erg hoog } \\ \text { Schilders } & 9.500 & 5,2 & \text { erg hoog } & 4,5 & \text { hoog } \\ \text { Leidinggevenden horeca } & 18.200 & 4,9 & \text { hoog } & 4,4 & \text { gemiddeld } \\ \text { Secretaresses en typisten } & 36.600 & 4,9 & \text { hoog } & 3,5 & \text { gemiddeld } \\ \text { Hogere leidinggevenden financiën, verkoop e.d26.300 } & 4,8 & \text { hoog } & 4,3 & \text { gemiddeld } \\ \text { Verpleegkundigen } & 29.600 & 4,8 & \text { hoog } & 4,1 & \text { gemiddeld } \\ \text { Metselaars en stukadoors } & 12.000 & 4,8 & \text { hoog } & 4,1 & \text { gemiddeld } \\ \text { Maatschappelijk werkers } & 17.900 & 4,7 & \text { hoog } & 3,0 & \text { laag } \\ \text { Dokters-, tandarts- en dierenartsassistenten } & 6.000 & 4,7 & \text { hoog } & 3,1 & \text { laag }\end{array}$

Bron: ROA (1995a)

Tabel 3.11 geeft een beeld van de beroepsklassen waarvoor de komende jaren een grote vervangingsvraag is te verwachten. Bij vervangingsvraag naar beroepsklasse gaat het niet per se om een stroom die de arbeidsmarkt verlaat, maar wordt gekeken naar het aantal werkenden dat het beroep verlaat. Absoluut gezien wordt de tabel vooral gedomineerd door beroepsklassen die zeer omvangrijk zijn, zoals ondernemers, uitvoerders en bedrijfskundigen, administrateurs en bankemployées en verkooppersoneel. Opvallend is dat ook programmeurs en systeemanalisten tot deze categorie behoren. Een aanzienlijk deel van de nog jonge beroepsgroep stroomt al door naar andere beroepen. Dit wordt waarschijnlijk veroorzaakt door de beperkte doorgroeimogelijkheden in de informaticabranche. Relatief gezien is vooral de hoge vervangingsvraag voor beleidsambtenaren opvallend. Door de leeftijdsopbouw bij deze 
beroepsklasse valt te verwachten dat de komende jaren een groot aantal beleidsambtenaren de arbeidsmarkt zullen verlaten. Dit betekent dat ondanks de krimpende werkgelegenheid bij de overheid toch het aantal baanopeningen hoog zal zijn.

\section{Mobiliteit van maand tot maand}

In de vorige paragraaf is ingegaan op stromen op de arbeidsmarkt die door hun globale karakter met name een beeld geven van de trendmatige verschuivingen op de langere termijn. Voor analyses die vooral deze globalere verschuivingen betreffen zijn stoomcijfers met betrekking tot de situatie op twee meetmomenten vaak afdoende en zou concretere informatie de complexiteit onnodig vergroten. Een belangrijk voorbeeld hiervan zijn de prognoses van vraag en aanbod per opleidingstype, waarvoor vooral deze globale in- en uitstroomverhoudingen, te zamen met de uitbreidingsvraag cruciaal zijn voor de arbeidsmarktperspectieven op middellange termijn. Als de interesse echter uitgaat naar het specifieke verloop van mobiliteitsprocessen op de arbeidsmarkt kunnen deze globale stroomcijfers, een misleidend beeld geven van de gebeurtenissen op de arbeidsmarkt. Gegevens die meer concrete informatie geven over de arbeidsmarktstromen op continue basis zijn dan vereist. De behoefte aan dergelijke meer diepgravende informatie doet zich met name voor als de positie van bepaalde specifieke categorieën op de arbeidsmarkt wordt geanalyseerd. Hierbij kan gedacht worden aan de intrede van schoolverlaters in het arbeidsproces en aan de positie van werklozen. In dit hoofdstuk wordt daarom op basis van stroomcijfers, die informatie geven over de veranderingen op de arbeidsmarkt van maand tot maand, een beeld gegeven van deze onderliggende stromen.

Het OSA-aanbodpanel bevat naast vragen over de maatschappelijke positie aan het begin en aan het einde van de onderzochte periode ook een retrospectieve vraag waarin de respondent gevraagd wordt alle veranderingen die in de afgelopen twee jaar zijn opgetreden op te geven. Op grond van deze informatie kan doorlopend de weg door het arbeidsproces gevolgd worden. Met behulp van deze gegevens zijn in tabel 4.1 de gemiddelde overgangen van maand op maand opgenomen. Voor elke opeenvolging van twee maanden kan een individu danwel geen verandering hebben ondergaan, danwel van positie zijn veranderd. Al deze mogelijke overgangen zijn samengenomen in de tabel, zodat voor ieder individu 23 mogelijke overgangen zijn opgenomen. Hierdoor komen overgangen aan het licht die in tabel 3.1 niet werden waargenomen. Zo blijkt bijvoorbeeld een deel van de dienstplichtigen eerste werkloos te zijn geworden alvorens ze na twee jaar allemaal werk bleken te hebben.

De overgangscijfers in tabel 4.1 zijn uiteraard kleiner dan in tabel 3.1, omdat het hier het aantal overgangen per maand en niet per twee jaar betreft. Zelfs als echter rekening wordt gehouden met dit periodeverschil, is het aantal overgangen van baan naar baan echter relatief kleiner dan in de globalere tabel 3.1. 23 maal 1,6\% baan-baan-wisselingen is immers kleiner dan de maandelijkse $43 \%$ waarvan sprake is in tabel 3.1. De oorzaak hiervoor is dat een deel van degenen die na twee jaar van baan zijn veranderd, tussen deze twee banen in enige tijd 
werkloos is geweest. In de tabel met maandelijkse overgangen wordt daarom een overgang van werk naar werkloos en een overgang van werkloos terug naar werk geregistreerd, terwijl de globalere tabel alleen de verandering van baan vaststelt. De gedetailleerde informatie van de retrospectieve vraag geeft bij zorgvuldige bestudering daarom een beter beeld van het exacte verloop van de mobiliteitsprocessen.

De gemiddelde overgangskansen van tabel 4.1 zouden in principe van maand tot maand gegeven kunnen worden, zodat de veranderingen in de dynamiek in de loop van de tijd in beeld gebracht zouden kunnen worden. Het aantal maandelijkse overgangen in de steekproef is echter niet voldoende om hieruit statistisch betrouwbare informatie te verkrijgen. Wel kunnen de overgangen van maand tot maand op andere manieren opgesplitst worden. Als voorbeeld worden in tabel 4.2 alleen de overgangen gepresenteerd van personen die eerder gedurende de waarnemingsperiode werkloos zijn geweest. De overgangen van deze specifiek geselecteerde groep blijken op bepaalde punten aanzienlijk te verschillen van de overgangen van de totale populatie. De groep blijkt als ze weer werkzaam zijn, veel vaker opnieuw werkloos te worden, maar ook blijkt men vaker van baan te wisselen.

\begin{tabular}{|c|c|c|c|c|c|c|c|c|}
\hline & $\begin{array}{l}\text { andere } \\
\text { functies } \\
\text { zelfde } \\
\text { werkkring } \\
\quad \%\end{array}$ & $\begin{array}{l}\text { loon- } \\
\text { dienst } \\
\begin{array}{r}9 \\
9\end{array}\end{array}$ & zelfstandige & meewerkend & $\begin{array}{l}\text { geen werk } \\
\text { op zoek }\end{array}$ & $\begin{array}{l}\text { geen werk } \\
\text { niet } \\
\text { op zoek } \\
\quad \%\end{array}$ & $\begin{array}{l}\text { dagop- } \\
\text { leiding }\end{array}$ & $\begin{array}{l}\text { geen } \\
\text { verandering }\end{array}$ \\
\hline $\begin{array}{l}\text { andere functies, } \\
\text { zelfde werkkring }\end{array}$ & 0,5 & 0,1 & 0,0 & 0,0 & 0,0 & 0,0 & 0,0 & 99,2 \\
\hline loondienst & 0,6 & 1,0 & 0,0 & 0,0 & 0,2 & 0,2 & 0,0 & 97,9 \\
\hline zelfstandige & 0,0 & 0,3 & 0,5 & 0,0 & 0,0 & 0,2 & 0,0 & 99,0 \\
\hline meewerkend & 0,0 & 0,2 & 0,2 & 0,3 & 0,0 & 0,2 & 0,0 & 99,0 \\
\hline geen werk, op zoek & 0,0 & 3,9 & 0,1 & 0,0 & 0,1 & 0,6 & 0,1 & 95,3 \\
\hline geen werk, niet op zoek & $\mathrm{k} 0,0$ & 0,3 & 0,0 & 0,0 & 0,1 & 0,0 & 0,0 & 99,5 \\
\hline dienstplicht & 0,0 & 6,8 & 0,4 & 0,4 & 0,8 & 0,0 & 0,0 & 91,5 \\
\hline dagopleiding & 0,1 & 4,0 & 0,1 & 0,0 & 0,5 & 0,1 & 0,2 & 95,1 \\
\hline
\end{tabular}


Tabel 4.2

Gemiddelde mobiliteit van maand op maand van personen die werkloos zijn of zijn geweest volgens OSA- aanbodpanel 1990-1992

\begin{tabular}{|c|c|c|c|c|c|c|c|c|}
\hline & $\begin{array}{l}\text { andere } \\
\text { functies } \\
\text { zelfde } \\
\text { werkkring } \\
\quad \% \\
\end{array}$ & $\begin{array}{l}\text { loon- } \\
\text { dienst } \\
\% \\
\% \\
\end{array}$ & zelfstandige & meewerkend & $\begin{array}{l}\text { geen werk } \\
\text { op zoek }\end{array}$ & $\begin{array}{l}\text { geen werk } \\
\text { niet } \\
\text { op zoek } \\
\% \\
\end{array}$ & $\begin{array}{l}\text { dagop- } \\
\text { leiding }\end{array}$ & $\begin{array}{l}\text { geen } \\
\text { verandering }\end{array}$ \\
\hline \multicolumn{9}{|l|}{ andere functie } \\
\hline loondienst & 0,3 & 2,4 & 0,0 & 0,0 & 2,0 & 0,3 & 0,0 & 95,0 \\
\hline zelfstandige & 0,0 & 1,7 & 5,2 & 0,0 & 0,0 & 0,0 & 0,0 & 93,1 \\
\hline meewerkend & 0,0 & 0,0 & 0,0 & 0,0 & 0,0 & 0,0 & 0,0 & 0,0 \\
\hline geen werk, op zoek & 0,0 & 2,3 & 0,1 & 0,0 & 0,1 & 0,3 & 0,1 & 97,1 \\
\hline geen werk, niet op zoe & 0,0 & 0,0 & 0,0 & 0,0 & 1,6 & 0,0 & 0,0 & 98,4 \\
\hline dienstplicht & 0,0 & 0,0 & 0,0 & 0,0 & 0,0 & 0,0 & 0,0 & 0,0 \\
\hline dagopleiding & 0,0 & 5,7 & 0,0 & 0,0 & 2,9 & 0,0 & 0,0 & 91,4 \\
\hline
\end{tabular}

Zoals reeds is opgemerkt is de onderzoekspopulatie van het OSA-aanbodpanel te klein om uitspraken te kunnen doen over de overgangen op de arbeidsmarkt van maand tot maand. Wel kan, met behulp van de retrospectieve vraag een reconstructie van de maandelijkse standcijfers worden gemaakt die een goed beeld geven van de feitelijke arbeidsmarktprocessen. Dit is gedaan in figuur 4.1 tot en met 4.3 waarin achtereenvolgens het aantal werkenden, het aantal studerenden en het aantal werklozen is gereconstrueerd.

Figuur 4.1

Geconstrueerde aandeel werkenden in OSA-aanbodpanel, 1990-1992

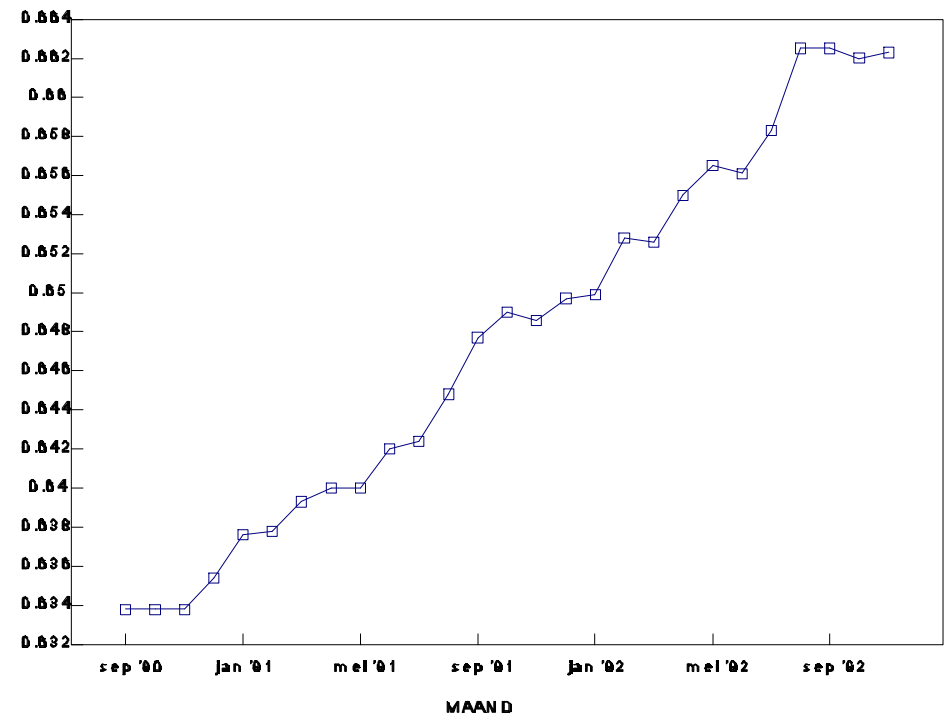

Deze maandcijfers zijn interessant omdat aan de ene kant verwacht kan worden dat de arbeidsmarktuitstroom gelijk verdeeld is over het jaar, terwijl de instroom van schoolverlaters geconcentreerd is rondom de zomer. Dat betekent dat na de zomer de beroepsbevolking relatief groot is, terwijl deze voor de zomer juist vrij klein zou moeten zijn. Voor de intrede van 
schoolverlaters is dit een cruciaal gegeven. Als de werkgelegenheid immers volledig vraagbepaald zou zijn, dan valt te verwachten dat met name in de tweede helft van het jaar het aanbod groter is dan de vraag, waardoor de werkloosheid onder schoolverlaters gedurende deze periode groot zou zijn. Gemiddeld zouden in dat geval pas na zes maanden werk vinden. Als echter de werkgelegenheid sterk aanbodbepaald is, valt te verwachten dat met name rond de zomer de werkgelegenheid sterk toeneemt. De figuren laten zien dat dit tweede het geval lijkt te zijn. De werkloosheid in september 1991 neemt licht toe, maar deze stijging valt in het niet bij de aantallen schoolverlaters in deze periode. Hoewel de uitstroom uit het onderwijs minder sterk geconcentreerd is rond de zomer dan wellicht verwacht zou worden, is in deze periode een duidelijk sterkere afname van het aantal personen in het onderwijs te zien dan in andere maanden. Het spiegelbeeld doet zich voor bij de werkgelegenheid die juist in deze maanden sterk stijgt. Omdat er naast de instroom van schoolverlaters simultaan sprake is van de uitstroom van werkenden is dit patroon echter minder geprononceerd.

Figuur 4.2

Geconstrueerde aandeel studerenden in OSA-aanbodpanel, 1990-1992

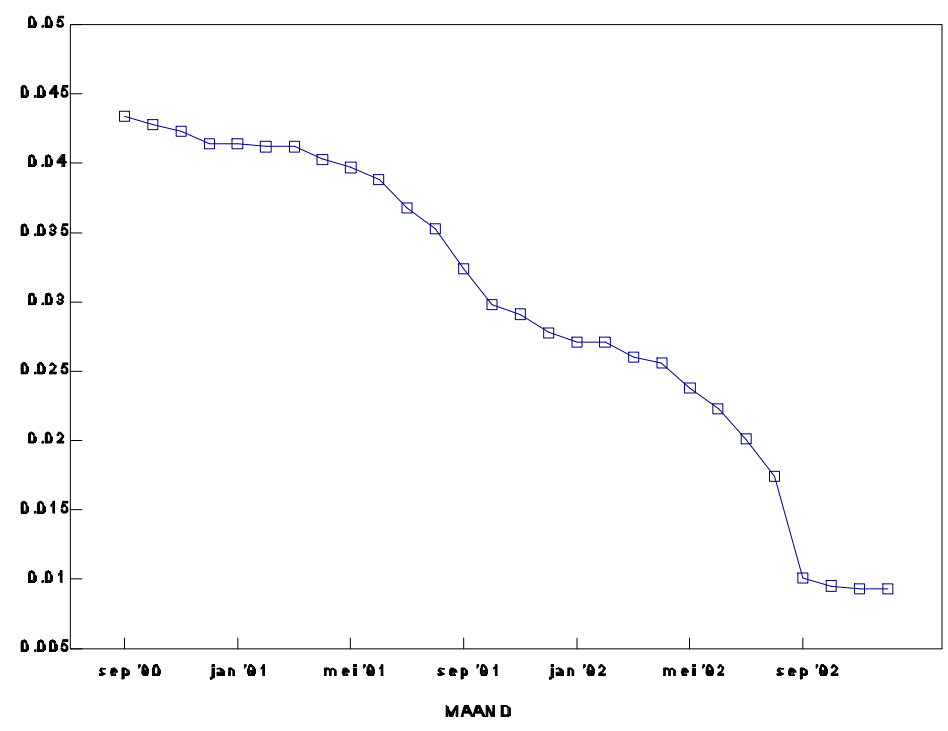

Het feit dat het aantal personen in het onderwijs doorlopend daalt is een artefact die ontstaat door het gebruik van een retrospectieve vraag. Omdat er geen kinderen in de steekproef zitten vertoont de figuur minder instroom in het onderwijs dan er feitelijk plaatsvindt. Met name als een retrospectieve vraag langer teruggaat in de tijd worden dergelijke vertekeningen omvangrijker. Bij sommige retrospectieve vragen wordt de gehele loopbaan van personen gereconstrueerd. Op de arbeidsmarkt van 20 jaar geleden bevonden zich echter ook personen die thans reeds overleden zijn, zodat deze groep ondervertegenwoordigd zal zijn in de standcijfers over het verleden. Een belangrijkere bron van fouten in een retrospectieve vraagstelling komt naar voren in figuur 4.3. Aan het begin en aan het einde van de waarnemingsperiode is de werkloosheid hoger dan in de tussenliggende periode. Deze 
inzinking wordt waarschijnlijk veroorzaakt doordat mensen korte werkloosheidsperioden vergeten op te geven. Omdat een aanzienlijk deel van de werkloosheid van korte duur is, wordt deze niet doorgegeven in de retrospectieve vraag, terwijl het panel op het moment van enquête wel nauwkeurig meet wie op dat moment werkloos is, ook al is dit slechts van korte duur.

Figuur 4.3

Geconstrueerde aandeel werklozen in OSA-aanbodpanel, 1990-1992

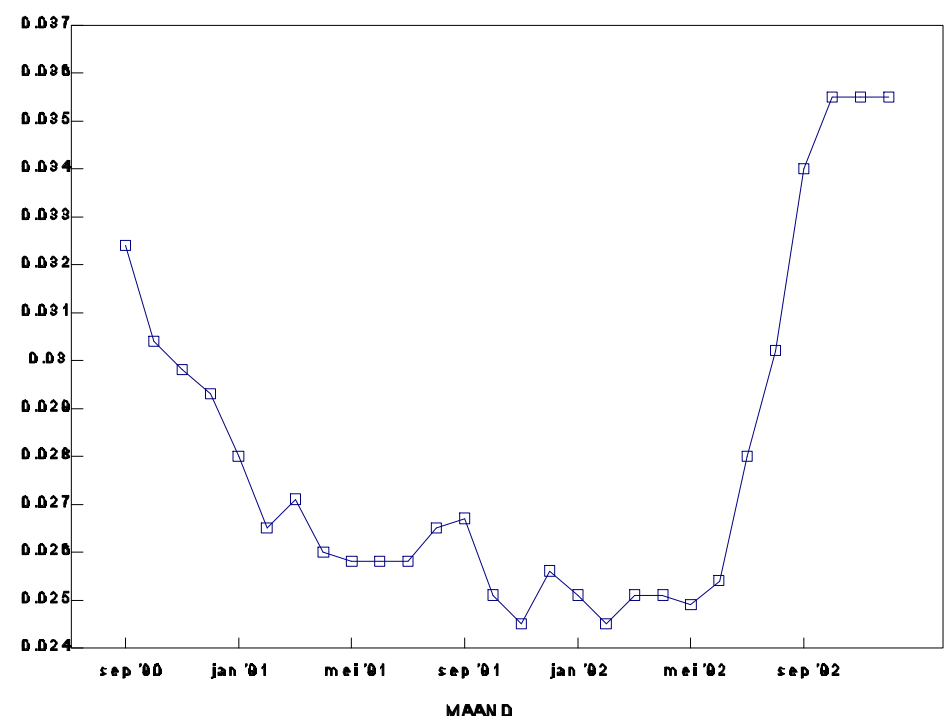

Met behulp van toegespitste enquêtes kunnen de specifieke arbeidsmarktprocessen van bepaalde doelgroepen nader in kaart worden gebracht. Dergelijke toegespitste enquêtes hebben als voordeel dat alleen de betreffende groep ondervraagd hoeft te worden. Tabel 3.1 liet immers al zien dat voor een groot deel van de arbeidsmarkt de veranderingen gering zijn, zodat omvangrijke enquêtes onder deze personen achterwege gelaten kunnen worden. De HBO-Monitor en RUBS zijn voorbeelden van dergelijke toegespitste enquêtes onder schoolverlaters. De schoolverlaters zijn een groep waarbij juist veel aansluitingsproblemen op de arbeidsmarkt te verwachten zijn en waarbij een nadere analyse van de dynamiek dus gewenst is. Op vergelijkbare wijze zou de mobiliteit van andere doelgroepen gevolgd kunnen worden. Hierbij kan bijvoorbeeld worden gedacht aan werklozen, allochtonen, herintrede arbeidsongeschikten, of een groep werknemers die vanwege collectief ontslag hun baan verliezen.

In de HBO-Monitor is een retrospectieve vraag opgenomen waarin de afgestudeerden van maand tot maand opgeven wat hun maatschappelijke positie was ${ }^{2}$. Figuur 4.4 laat zien hoe

2. Met ingang van 1996 zal een vergelijkbare vraag in de RUBS-enquête worden opgenomen. 
voor de afgestudeerden in 1993 uit het HBO de overgang van school naar de arbeidsmarkt is verlopen. Rond juli 1993 vertoont de grafiek een grote afname van het aandeel dat nog studeert, terwijl tegelijkertijd zowel het percentage werkenden als het percentage personen met een andere activiteit (waaronder werkloosheid) stijgt. Na verloop van tijd neemt het aandeel afgestudeerden dat niet werkt en niet studeert weer af, terwijl het aantal werkenden blijft stijgen.

Figuur 4.4

Overgang van school naar werk op basis van HBO-Monitor (1994) in kalendertijd, percentage

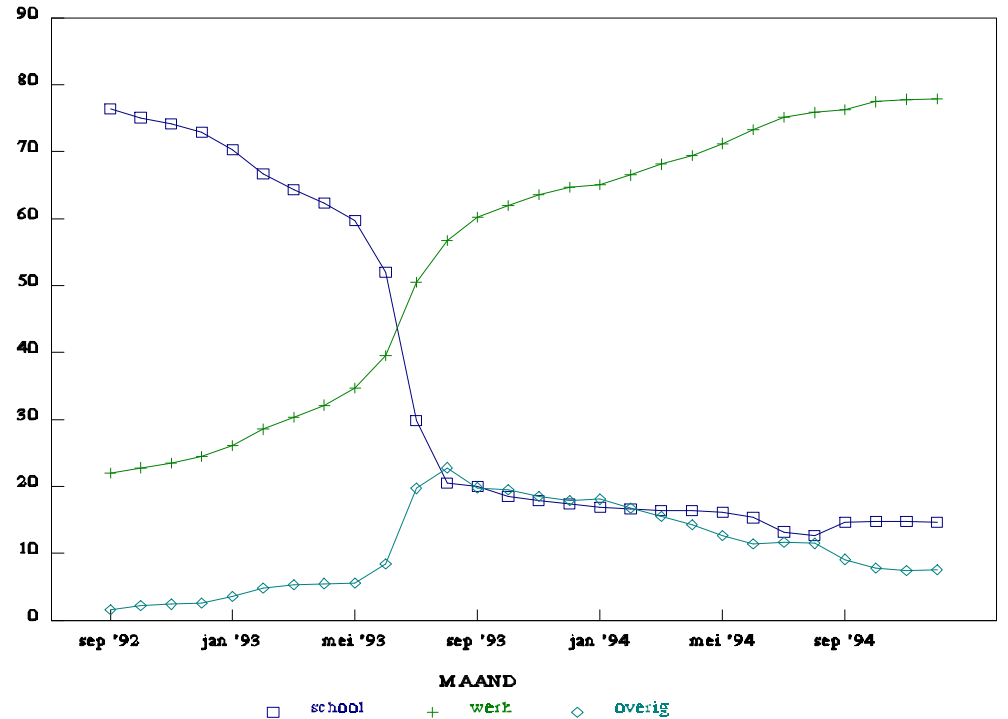

De geleidelijke overgang van studie naar werk in figuur 4.5 wordt voor een deel veroorzaakt doordat het moment van afstuderen niet gelijk valt voor alle studenten. In figuur 4.5 wordt daarom dezelfde informatie gegeven, gemeten in maanden na het afstuderen in plaats van in kalendertijd. Doordat de gegevens in hele maanden worden verzameld kan er een discrepantie bestaan tussen het moment van afstuderen en de positie op de arbeidsmarkt in die maand, afhankelijk van de vraag of men aan het begin of aan het einde van de maand is afgestudeerd. De grafiek vertoont daardoor in de eerste periode een sterke discontinuïteit. In maand 1 blijkt echter de meerderheid van de afgestudeerden reeds te werken. Dit percentage werkenden neemt daarna gestaag verder toe. 
Figuur 4.5

Overgang van school naar werk op basis van HBO-Monitor in maanden na afstuderen, percentage

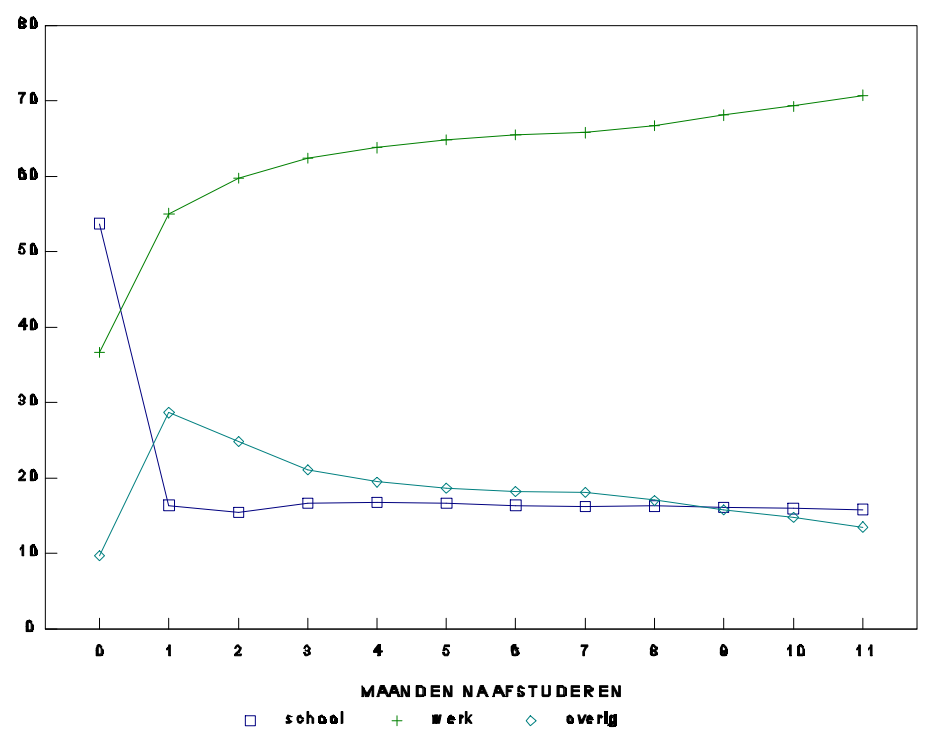

Achter dit geleidelijke intredeproces blijkt echter een opmerkelijk grote dynamiek schuil te gaan. Figuur 4.5 lijkt te suggereren dat de groep werkloze schoolverlaters langzaam afneemt, maar in werkelijkheid blijkt de groep niet werkenden te zijn samengesteld uit schoolverlaters die nog geen baan hebben gehad en een groep die na de eerste (of tweede) baanperiode alweer werkloos is geworden.

Tabel 4.3

Aantal banen dat een schoolverlater uit het HBO heeft in eerste anderhalf jaar na afstuderen (HBOMonitor 1994)

Aantal $\%$

banen

$\begin{array}{lr}0 & 11,7 \\ 1 & 44,9 \\ 2 & 24,1 \\ 3 & 10,6 \\ 4 & 4,3 \\ 5 & 2,1 \\ 6 & 0,9 \\ 7 & 0,5 \\ 8 & 0,2 \\ 9 & 0,6\end{array}$

Tabel 4.3 geeft aan hoeveel banen een afgestudeerde HBO'er anderhalf jaar na afstuderen heeft gehad. Uit deze tabel blijkt iets minder dan de helft van de afgestudeerden op het moment van enquête in reeds twee of meer banen werkzaam zijn geweest. Het blijkt dat een 
meerderheid van de afgestudeerden na anderhalf jaar reeds in meer dan één baan werkzaam is geweest. Meer dan 10\% zit reeds in de derde baan, terwijl $8,6 \%$ zelfs meer dan drie banen heeft gehad.

Figuur 4.6

Aandeel studenten/afgestudeerden voor en tijdens eerste en tweede baanperiode (HBO-Monitor 1994) 
Figuur 4.6 laat grafisch de consequenties van deze dynamiek zien. In het bovenste deel van de grafiek staat het aantal HBO'ers weergegeven, dat nog niet in de eerste baan werkzaam is. Deze groep is derhalve nog bezig met de studie of is afgestudeerd, maar heeft nog geen baan gevonden. Ook degenen die niet op zoek zijn naar werk zijn in deze categorie opgenomen. Het tweede deel van de grafiek toont de toename van het aantal werkenden in een eerste periode van werk. Op grond van de cijfers in de HBO-Monitor kunnen twee banen die elkaar onmiddellijk opvolgen niet afzonderlijk worden waargenomen. In de figuur staat daarom het aantal afgestudeerden dat in de eerste baanperiode zit weergegeven. De derde grafiek in figuur 4.6 geeft vervolgens aan hoeveel afgestudeerden deze eerste baanperiode alweer hebben afgesloten en (weer) werkloos zijn, of om een andere reden niet meer werken. Ten slotte laat de vierde grafiek de groei van het aantal afgestudeerden zien, die reeds in de tweede baanperiode zitten. De grafiek zou kunnen worden voortgezet met opvolgende fases, maar het aantal afgestudeerden in deze situatie wordt snel kleiner. Van belang is echter dat de grafiek laat zien, dat de ontwikkeling van het aantal personen met of zonder baan zoals weergegeven in figuur 4.4, niet louter de overgang van school via een periode zonder werk naar werk weerspiegelt, maar dat gelijktijdig met deze intredeprocessen andere schoolverlaters alweer hun baan verliezen en (weer) werkloos worden.

Tabel 4.4 laat zien hoe sterk deze arbeidsmarktmobiliteit na afstuderen is voor de verschillende onderwijsniveaus. De tabel laat in tegenstelling tot tabel 3.6 degenen die op het moment van enquête nog geen werk hebben gehad buiten beschouwing en geeft van de overigen aan of men een of reeds meerdere banen heeft gehad. Hierbij dient wel de kanttekening gemaakt te worden dat alleen de HBO'ers anderhalf jaar na afstuderen zijn geënquêteerd. De andere opleidingsniveaus, waarvan de informatie uit RUBS komt, zijn ongeveer negen maanden na schoolverlaten ondervraagd. De hogere mobiliteit van HBO'ers zou mede door dit verschil veroorzaakt kunnen zijn, hoewel ook het CBS (tabel 3.6) een hogere mobiliteit onder hoger opgeleiden constateert. Verder is opmerkelijk dat de schoolverlaters van HAVO en VWO na negen maanden vaak minstens al in twee banen werkzaam zijn geweest. Kennelijk zijn met name deze schoolverlaters uit het algemeen onderwijs relatief mobiel.

Tabel 4.4

Percentage van de afgestudeerden die werken of werk hebben gehad dat in een of in meerdere banen heeft gewerkt per opleidingsniveau

\begin{tabular}{lrr} 
& één baan & $\begin{array}{r}\text { meerdere } \\
\text { banen }\end{array}$ \\
\hline MAVO & $\%$ & $\%$ \\
HAVO & 63 & 37 \\
VWO & 31 & 69 \\
VBO & 31 & 69 \\
KMBO & 73 & 27 \\
LLW & 64 & 36 \\
MBO & 69 & 31 \\
HBO & 63 & 37 \\
& 49 & 51
\end{tabular}


Vanwege de grote dynamiek op de arbeidsmarkt van afgestudeerden kunnen met name bij deze groepen te globale cijfers, die alleen de overgangen in positie op bepaalde momenten weergeven, zonder daarbij de mobiliteit in de tussenliggende periode te betrekken een vertekend beeld van de ontwikkelingen geven. Borghans en Willems (1995) laten dan ook zien dat een onderzoek van SEO/CBS met betrekking tot de baanzoekduur van schoolverlaters (Berkhout en Provoost, 1994) tot een enorme overschatting van deze zoekduur leidt, mede vanwege het feit dat in de EBB de tussentijdse dynamiek niet wordt waargenomen (zie ook Berkhout, 1996 en Borghans en Willems, 1996a).

Tabel 4.5

Zoekduur van schoolverlaters HBO voor en na afstuderen, 1994

\begin{tabular}{|c|c|c|c|c|}
\hline $\begin{array}{r}\text { zoekduu } \\
\text { einde } \\
\text { ma }\end{array}$ & $\begin{array}{l}\text { voor } \\
\text { tudie } \\
\text { nden }\end{array}$ & $\begin{array}{r}\text { aandeel } \\
\text { onmiddellijke } \\
\text { werk } \\
\%\end{array}$ & $\begin{array}{r}\text { zoekduur na } \\
\text { einde studie } \\
\text { maanden }\end{array}$ & $\begin{array}{r}\text { gemiddelde } \\
\text { zoekduur } \\
\text { maanden }\end{array}$ \\
\hline HBO onderwijs & 1,7 & 43 & 3,8 & 2,0 \\
\hline HBO landbouw en milieukunde & 2,2 & 62 & 6,3 & 2,3 \\
\hline HBO technisch laboratorium & 2,4 & 53 & 6,0 & 2,6 \\
\hline HBO (weg-en water)bouwkunde & 1,3 & 66 & 3,4 & 1,2 \\
\hline HBO werktuigbouwkunde & 1,2 & 61 & 5,8 & 2,1 \\
\hline HBO elektrotechniek en technische informatica & 1,3 & 61 & 5,3 & 1,9 \\
\hline HBO medisch laboratorium & 2,4 & 57 & 3,8 & 1,5 \\
\hline HBO verpleging en paramedisch & 1,5 & 61 & 4,0 & 1,4 \\
\hline HBO bedriifseconomie & 1,8 & 67 & 3,4 & 1,1 \\
\hline HBO accountancy & 1,5 & 76 & 6,1 & 1,5 \\
\hline HBO bedrijfsinformatica & 1,7 & 69 & 3,7 & 1,1 \\
\hline HBO toerisme en recreatie & 0,9 & 62 & 3,6 & 1,3 \\
\hline HBO commerciële economie & 1,2 & 62 & 3,7 & 1,4 \\
\hline HBO technische bedrijfskunde & 1,6 & 53 & 5,3 & 2,4 \\
\hline HBO bestuurlijk-juridisch & 1,8 & 66 & 3,7 & 1,2 \\
\hline HBO sociaal-cultureel & 1,7 & 59 & 5,4 & 2,1 \\
\hline HBO kunst & 1,1 & 26 & 10,9 & 7,9 \\
\hline
\end{tabular}

Tabel 4.5 geeft een overzicht van de gemiddelde zoekduur tot de eerste baanperiode van minstens drie maanden voor een aantal HBO-richtingen (Borghans en Willems, 1996b). Het blijkt dat een groot deel van de schoolverlaters reeds werk heeft op het moment van afstuderen. Voor bijna alle richtingen op het HBO betreft dit meer dan 50\%. De enige uitzonderingen zijn de opleidingen HBO onderwijs en HBO kunst. De gemiddelde zoekduur van degenen die na het afstuderen nog geen werk hebben varieert tussen 3,4 maanden voor HBO (weg-en water)bouwkunde en HBO bedrijfseconomie tot 10,9 maanden voor HBO kunst. Omdat een groot deel van de afgestudeerden echter een zoekduur van 0 maanden heeft varieert de gemiddelde zoekduur van alle afgestudeerden tussen 1,1 maand voor HBO bedrijfseconomie en HBO bedrijfsinformatica tot 7,9 maand voor HBO kunst. Het feit dat afgestudeerden reeds bij afstuderen werk hebben gevonden wijst erop dat het zoekproces 
reeds voor het afstuderen begint. De tabel laat zien dat gemiddeld 1 tot 2,5 maanden voor afstuderen met zoeken wordt gestart. Deze korte zoekperiode is gemiddeld derhalve vrij succesvol. Borghans en Willems (1996b) laten zien dat de invloed van een langere zoekperiode vóór het afstuderen op de kans om reeds bij afstuderen werk te hebben echter slechts gering is.

In CBA (1996) wordt op basis van de EBB een beeld gegeven van de werkloosheid onder schoolverlaters. Deze staan weergegeven in tabel 4.6 De werkloosheidspercentages zijn opvallend hoog. Ook hier geldt echter dat vanwege de grote dynamiek op de arbeidsmarkt van schoolverlaters de vaststelling van de werkloosheid erg gevoelig is voor de wijze van meten.

Tabel 4.6

Werkloosheid onder schoolverlaters op basis van EBB

Werkloosheid

$\%$

\begin{tabular}{ll}
\hline Basisonderwijs/Mavo & 33 \\
VBO & 26 \\
HAVO,VWO & 23 \\
MBO & 25 \\
HBO & 29 \\
WO & 39
\end{tabular}

Totaal 28,2

De EBB bevat in ongeveer gelijke mate schoolverlaters die 0 tot 12 maanden geleden hun opleiding hebben afgesloten. De percentages in tabel 4.6 zijn derhalve een gemiddelde van de werkloosheidspercentages voor deze verschillende groepen. Als iedere maand een gelijk deel van de werkloze schoolverlaters werk zou vinden, dan komen de vermelde percentages echter overeen met een gemiddelde zoekduur van ongeveer 3 maanden.

Niet alleen de schoolverlaters, maar ook de werklozen vormen uiteraard een groep waarvoor een nauwkeurige monitoring van de arbeidsmarktdynamiek van belang is. Figuur 4.7 laat een schatting van Kerckhoffs, de Neubourg en Palm (1994) zien waarin de geschatte kans op het vinden van een baan door een werkloze op grond van een aantal modellen is uitgezet tegen de werkloosheidsduur. Opmerkelijk is dat deze kans aanvankelijk stijgt. Na enkele maanden gaat deze kans echter dalen. De toename van de baanvindkans gedurende de eerste maanden wordt waarschijnlijk veroorzaakt doordat sollicitatieprocedures enige tijd in beslag kunnen nemen. Als de werkloze niet in de gelegenheid was om reeds voor ontslag of het einde van zijn contract op zoek te gaan naar ander werk zal het zelfs bij een succesvolle sollicitatie reeds enkele maanden duren voordat het werk in een nieuwe baan kan starten. 
Figuur 4.7

De baanvindkans van werklozen afhankelijk van de werkloosheidsduur volgens Kerckhoffs, De Neubourg en Palm (1994)

\section{Conclusies}

In deze notitie is een overzicht gegeven van de beschikbare stroomgegevens met betrekking tot de Nederlandse arbeidsmarkt. Doel hiervan was om zowel een kwantitatief beeld te krijgen van deze arbeidsmarktstromen, als na te gaan welke beperkingen de thans beschikbare bronnen opleggen bij het in kaart brengen van de stromen.

Geconcludeerd kan worden dat standcijfers en meer globale stroomcijfers veelal een vertekenend beeld geven van de feitelijke processen op de arbeidsmarkt. Er blijkt veelal sprake te zijn van een grote dynamiek die niet in de globale cijfers tot uitdrukking komt. Illustratief in dit opzicht is het feit dat van de werkloze afgestudeerden uit het HBO, die ongeveer anderhalf jaar na afstuderen zijn ondervraagd, een behoorlijk deel na afstuderen werk heeft gehad, maar dit alweer is kwijtgeraakt. Cijfers die alleen de situatie op een bepaald moment weergeven suggereren daarom ten onrechte dat deze groep reeds vanaf het moment van afstuderen werkloos is. Hoewel voor bepaalde analyses deze onderliggende dynamiek minder belangrijk is, zal voor ander onderzoek een gebrek aan data op dit punt tot verkeerde conclusies kunnen leiden.

De belangrijkste bronnen voor stroomcijfers over de volle breedte van de arbeidsmarkt zijn momenteel het OSA-aanbodpanel en het Sociaal-Economisch Panel van het CBS. Beide panels hebben echter betrekking op een betrekkelijke kleine steekproef. Voor verbijzonderingen naar bedrijfssector, beroep, opleidingsachtergrond, leeftijd e.d. bieden deze panels daarom statistisch gezien geen mogelijkheden. Dergelijke verbijzonderingen blijken echter wel zeer relevant te zijn. Een alternatief in dit opzicht wordt gevormd door de Enquête Beroeps-Bevolking (EBB) van het CBS. Deze enquête heeft een veel grotere steekproefomvang en bevat ook retrospectieve vragen. Er is tot op heden echter slechts zeer 
sporadisch gebruik gemaakt van deze stroomgegevens. Daarnaast kan zeer nuttige informatie over stromen op de arbeidsmarkt worden verkregen door bijzondere groepen, waarbij een grote mobiliteit verwacht kan worden, te monitoren. Een voorbeeld hiervan zijn de schoolverlatersenquêtes RUBS en HBO-Monitor. Op vergelijkbare wijze zouden ook andere doelgroepen gevolgd kunnen worden. Hierbij kan bijvoorbeeld gedacht worden aan werklozen, allochtonen, herintredende arbeidsongeschikten of een groep werknemers die vanwege collectief ontslag hun baan verliezen. Buiten de schoolverlatersenquêtes is er momenteel echter geen systematisch onderzoek beschikbaar naar de arbeidsmarktmobiliteit van dergelijke specifieke groepen.

\section{Literatuur}

Berkhout, P.H.G. (1996), Baanzoekduren van HBO'ers verder uitvergroot, een repliek, in: Tijdschrift voor Arbeidsvraagstukken, jrg. 12, nr. 1, pp. 56-59.

Blanchard, O.J., P. Diamond (1989), The Beveridge Curve, Brookings Papers on Economic Activity, pp. 1-60.

Borghans, L., E. Willems (1995), Baanzoekduren van HBO'ers onder de loep, in: Tijdschrift voor Arbeidsvraagstukken, jrg. 11, nr. 4, pp. 348-357.

Borghans, L., E. Willems (1996a), Baanzoekduren van HBO'ers en de waarde van een vergrootglas, een dupliek, in: Tijdschrift voor Arbeidsvraagstukken, jrg. 12, nr. 1, pp. 60-61.

Borghans, L., E. Willems (1996b), Pre-graduation Search and the Unemployment of School-leavers,

$\mathrm{p} \quad \mathrm{a}$

gepresenteerd op het AEA-congres in Göteborg.

Brink, M., M. Pasariboe, M. Hollands (1996), Integratie van vluchtelingen op de arbeidsmarkt, Amsterdamse Sociaal-Geografische Studies, Amsterdam.

Broersma, L., P.A. Gautier (1995), Vernietiging en creatie van banen in de industrie, in: Economisch Statistische Berichten, pp. 685-689.

Glebbeek, A.C. (1993), Perspectieven op loopbanen, Proefschrift, Groningen.

Grip, A. de, P. Meijboom, E. Willems (1993), Vacancies, Employment Growth and the Demand for Newcomers on the Labour Market, in: J. Muysken (ed.) Measurement and Analysis of Job Vacancies, Avebury, Aldershot/Brookfield (USA), pp. 101-125.

Hofmans, M.G. (1996), 'De arbeidsmobiliteit van werknemers'. Sociaal-Economische Maandstatistiek, Jaargang 13, januari, pp. 9-11, Heerlen.

Kerckhoffs, C., C. de Neubourg, F. Palm (1994), The Determinants of Unemployment and Jobsearch Duration in the Netherlands, De Economist, 142, pp. 21-42.

Kunnen, R., W.C.M. Praat, H.R.M. Smulders, A.M. de Voogd-Hamelink, J.P.M. Vosse, J.M. van Werkhooven (1995), Trendrapport aanbod van arbeid 1995, OSA-rapport nr. 21, Den Haag.

Ministerie van Onderwijs, Cultuur en Wetenschappen (1995), Referentieraming 1995, Zoetermeer.

Researchcentrum voor Onderwijs en Arbeidsmarkt (1995a), De arbeidsmarkt naar opleiding en beroep tot 2000, ROA-R-1995/3, Maastricht.

Researchcentrum voor Onderwijs en Arbeidsmarkt (1995b), Statistische Bijlage bij de arbeidsmarkt naar opleiding en beroep tot 2000, ROA-R-1995/3B, Maastricht.

Trimp, L. (1996), 'Sociaal-economische mobiliteit 1989-1993'. Sociaal-Economische Maandstatistiek, Jaargang 12, oktober, pp. 15-21, Heerlen.

Willems, E.J.T.A., A. de Grip (1993), Forecasting Replacement Demand by Occupation and Education, in: International Journal of Forecasting, jrg. 9, pp. 173-185. 